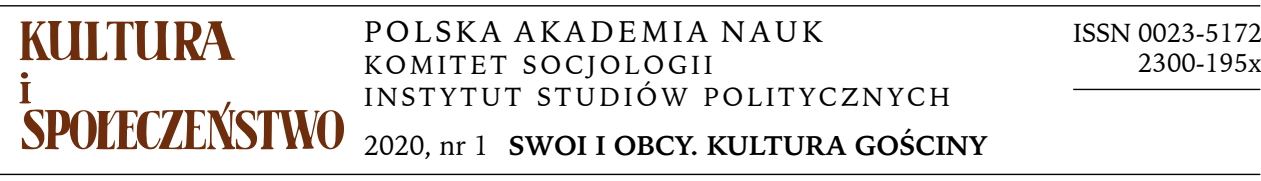
$\begin{array}{llllllll}A & R & T & Y & K & U & Ł & Y\end{array}$
I
$\begin{array}{llllllll}\mathrm{R} & \mathrm{O} & \mathrm{Z} & \mathrm{P} & \mathrm{R} & \mathrm{A} & \mathrm{W} & \mathrm{Y}\end{array}$

MARTA SKOWROŃSKA

Uniwersytet im. Adama Mickiewicza

\title{
KLASOWY WYMIAR GOŚCINNOŚCI: ZRÓŻNICOWANIE DYSPOZYCJI ORGANIZUJĄCYCH PRAKTYKI GOŚCINY
}

\section{WPROWADZENIE}

Badania gościnności w socjologii są dość trudne do odnalezienia. Sądzę, że taki stan rzeczy ma kilka przyczyn. Pierwsza i chyba najważniejsza to ta, że niejednokrotnie mówimy o gościnie, używając innych słów. Gościnność kryje się w innych, pokrewnych kategoriach; nie jest omawiana wprost (więcej na ten temat zob. Pisarek 2016; Mateja, Skowrońska 2019). Poszukując tropów gościny w naukach społecznych, natrafiamy po pierwsze - na uniwersalny problem rozdźwięku między swojskością a obcością, tożsamością a odmiennością. Praktyki gościny dotyczą mediowania i oswajania obcości, odmienności, otwierania się na obcego. Tego typu refleksja jest mocno obecna w filozofii (Derrida 2000, 2004), a także w socjologii, choćby w analizach migracji, stereotypów i uprzedzeń (Rosello 2001). Drugi istotny trop w poszukiwaniu badań gościny to analizy daru i wymiany (Douglas, Isherwood 1979; Mauss 2011). Matei Candela i Giovanni da Col sugerują wręcz, że możliwe byłoby zamienne używanie terminów „gościnność” i „dar” - ich tropy interpretacyjne są podobne. Gościnność, podobnie jak dar, wymaga wzajemności, wiąże się z napięciem

Adres do korespondencji: skowronska.marta@gmail.com; ORCID: 0000-0003-4335$-6288$ 
między spontanicznością a kalkulacją, przyjaźnią i wrogością, improwizacją i kontrolą (Candela, da Col 2012, s. S3-S4). Problematyka daru wydaje się zawłaszczona przez antropologię. Socjologia może jednak sięgnąć do teorii wymiany (Homans 1958), a także różnych teorii średniego zasięgu, jak teoria rytuału interakcyjnego (Goffman 2006) czy norm grupowych. Pokrewny trop poszukiwania gościny w naukach społecznych to również biesiady, ucztowanie i święta. Choć tradycyjnie łączone $z$ antropologią, obecnie stały się też przedmiotem interdyscyplinarnych food studies (Albala 2013). Trop biesiady i uczty prowadzi też do analizy towarzyskości (Simmel 2005), towarzyskość zaś - do szerszej refleksji nad formami uspołecznienia i kształtem więzi społecznych. Tematu gościny można poszukiwać również $\mathrm{w}$ pracach poświęconych praktykom kulturalnym — jak uczynili autorzy raportu Praktyki kulturalne Polaków - czyniąc z przyjmowania gości element relacji więziotwórczych (Drozdowski i in. 2014).

Poza wieloznacznością gościnność przysparza też problemów ze względu na swoje normatywne zabarwienie. Bycie gościnnym to w polskiej kulturze wysoko ceniona wartość. W 2010 roku w badaniach Centrum Badania Opinii Publicznej (Hermann 2010) ankietowani proszeni o określenie, z czego Polacy jako ogół społeczeństwa mogą być dumni, w pierwszej kolejności wskazali gościnność (51\%). W 2015 roku gościnność została wybrana przez $8 \%$ ankietowanych jako najcharakterystyczniejsza polska cecha (po pracowitości $-25 \%$, malkontenctwie $-17 \%$, serdeczności $-12 \%$ i zaradności - 10\%; Omyła-Rudzka 2015). W badaniach „Polacy o sobie”, przeprowadzonych dla „Polityki” przez Kantar Public w lipcu 2017 roku (Cieśla 2017), ankieterzy poprosili 1000 dorosłych osób, by wskazały, które cztery cechy (z gotowej listy) najlepiej charakteryzują Polaków. Na pierwszym miejscu znalazła się gościnność, wskazana przez $63 \%$ pytanych. Gościnność pozostaje zatem istotną cechą autodefinicyjną Polaków. Taka interpretacja gościnności rodzi pewne problemy badawcze. Gościnność może być traktowana jako cecha, którą się ma lub nie — przy czym mieć się ją powinno.

$\mathrm{Z}$ tego powodu badania, których wyniki stanowiły podstawę tego tek$\mathrm{stu}^{1}$, były zaprojektowane $\mathrm{w}$ ten sposób, by gościnę traktować nie jako normę, ale jako praktykę społeczną²; praktykę odwiedzania czyjegoś domu

\footnotetext{
${ }^{1}$ Badania prowadzone były w ramach grantu Archiwum Badań nad Życiem Codziennym, realizowanego w latach 2014-2019 dzięki dofinansowaniu Narodowego Programu Rozwoju Humanistyki (nr 0065/NPRH3/H11/82/20), pod kierownictwem Marka Krajewskiego. Projekt badawczy obejmował między innymi zgromadzenie i udostępnienie szerokiej publiczności materiałów badawczych i publikacji naukowych dotyczących codzienności, które powstawały $\mathrm{w}$ Polsce $\mathrm{w}$ ciągu ostatnich stu lat, oraz tworzenie materiałów empirycznych, które kontynuują wybrane tradycje polskich badań nad codziennością. Wyniki badań zostały
} 
i bycia odwiedzanym w swoim domu. Mimo pokus, jakie stwarza wieloznaczność terminu „gościna”, zespół badawczy zdecydował się odciąć wszystkie inne kłącza tematyczne tego terminu, takie jak kwestie uchodźctwa, tolerancji, a także bycia gościem i gospodarzem we wszystkich kontekstach poza przestrzenią mieszkalną. Badania były prowadzone w trzech miejscowościach w województwie lubuskim, w latach 2017-2018. Zastosowano trzy metody badawcze: analizę materiałów osobistych (przeprowadzono konkurs pamiętnikarski, „O gościach i w gościach. Oblicza gościnności”, na który nadeszły 22 prace), wywiadów pogłębionych oraz obserwacji. Miejscowości dobrano tak, by łączyła je wielkość, ale dzieliły inne wskaźniki (w tym zwłaszcza odległość od głównych szlaków komunikacyjnych, poziom wydatków na kulturę oraz zamożność mieszkańców). Zakładano, że przy doborze uczestników do badań zostaną uwzględnione: przedział wiekowy respondentów, ich wykształcenie, status socjoekonomiczny oraz płeć. Ostatecznie problemy z rekrutacją sprawiły, że w próbie znalazło się nieproporcjonalnie wiele osób $z$ wykształceniem wyższym oraz kobiet. Udało się natomiast zachować zróżnicowanie wiekowe. Uwzględniono także po dwa wywiady w każdym $z$ miast $z$ tzw. ekspertami codzienności, czyli „osobami narażonymi na codzienności innych” (Borkowska, Jakubowska, Podgórski 2009, s. 88-89): listonoszami i księżmi. Łącznie przeprowadzono 60 wywiadów. Pytania wywiadu koncentrowały się na praktykach goszczenia. W dużej mierze uwzględniały wspomnienia wizyt u innych osób oraz odwiedzin gości we własnym domu. Dotyczyły też wyobrażonych sytuacji gościny (pytania projekcyjne — o sytuacje trudne, nietypowe). W pewnym stopniu scenariusz dotykał też metaforycznego rozumienia gościnności oraz gościnności zapośredniczonej przez media.

\section{GOŚCINA: PRAKTYKA SPOŁECZNA UWIKŁANA W PODZIAŁY KLASOWE}

Potraktowanie gościny jako praktyki społecznej daje szerokie możliwości interpretacyjne. Pozwala uwolnić się od normatywnego bagażu kategorii „gościnność”, od pytania o to, „czy Polacy są gościnni”, i pójść w stronę ugruntowania tego, co ta kategoria oznacza, co się na nią składa oraz jak różnicuje ona odwiedzanie i bycie odwiedzanym. Teorie praktyki proponują drogę, która wykracza zarówno poza model celowo-racjonalny, jak

opublikowane w formie książki Gość w dom. Wspótczesne praktyki przyjmowania gości pod redakcją Bogumiły Matei-Jaworskiej i Marty Skowrońskiej (2019).

${ }^{2}$ Karin Knorr-Cetina (2001, s. 184) definiuje praktyki jako „powtarzalne procesy regulowane przez określone schematy preferencji i zasad działania”. 
i deterministyczny (Reckwitz 2002) - punktem wyjścia jest to, co ludzie robią i mówią, ujmowane relacyjnie i kontekstowo. Bardzo istotne jest też to, że praktyka powinna być ujmowana szeroko, z uwzględnieniem ciała, emocji, wiedzy milczącej i przedmiotów (Reckwitz 2002). Choć badacze reprezentujący teorie praktyk (od Bourdieu przez Giddensa do Reckwitza, Schatzkiego i Knorr-Cetiny) spierają się co do szczegółów związku między praktykami a strukturą społeczną, istnieje ogólna zgoda na to, że w sposobach działania - jedzenia, mieszkania, przemieszczania się - można dostrzec cechy struktury społecznej, które zarówno warunkują przebieg praktyk, jak i ulegają w ich toku aktualizacji i modyfikacjom (Schatzki 2002).

Celem tych rozważań jest przyjrzenie się praktykom gościny w ich uwikłaniu w proces odtwarzania i modyfikowania struktury społecznej. W tym, co ludzie robią odwiedzając innych i będąc odwiedzanym, i jak o tym mówią, chciałabym poszukać pewnych ogólniejszych regularności i wzorów; w języku Pierre'a Bourdieu (2005) — zasad organizujących praktyki, będących elementami klasowego habitusu. W ostatnich latach pojęcie klasy społecznej nie jest dominującą narracją w polskiej socjologii - głośnym echem odbiły się tezy o zaniku klas (Pakulski, Waters 1996; Pakulski 2005). Sceptycyzm dotyczący sensu analizy klasowej w dużej mierze wiąże się ze skomplikowaną historią naszego kraju (nieciągłość struktury społecznej, szybkie awanse, brak tradycji klasy średniej; zob. np. Leder 2014), ale też ze zmianami społecznymi, takimi jak wzrost pluralizmu i indywidualizmu (Jacyno 2007; Marody, Giza-Poleszczuk 2004). Należy jednak zauważyć, że na przykład w brytyjskiej socjologii (Savage 2003; 2016; Devine 2004) pojawia się wiele badań wskazujących na to, że pluralizm kulturowy, wzrost indywidualizmu oraz rozkwit kultury popularnej nie doprowadziły do zaniku klas, ale raczej do rozdrobnienia i skomplikowania podziałów społecznych. Innymi słowy, analiza klasowa wyrastająca $z$ marksowskich i weberowskich tradycji może być trudna do obrony, jednak równie trudno byłoby obronić tezę o zaniku społecznych hierarchii i podziałów ${ }^{3}$. Obecnie analizy klasowe (Zarycki 2012; Gdula, Lewicki, Sadura 2014; Cebula 2017) częściej prowadzone są w duchu kulturalistycznym. Nie chodzi tu o wiązanie pozycji klasowej z uczestnictwem w kulturze w wąskim, instytucjonalnym sensie, ale o uwzględnienie kapitału kulturowego w rozumieniu, jakie nadał mu Pierre Bourdieu — wcielonych dyspozycji i schematów percepcji. Wyodrębnienie przez Bourdieu

${ }^{3}$ W tym tekście nie ma miejsca na bardziej szczegółowe omówienie współczesnych teorii klas. Świetnie podsumowuje tę problematykę Michał Cebula (2017). 
kapitału kulturowego, a także dwóch innych - ekonomicznego i społecznego, pozwoliło zrelatywizować i zniuansować pozycje klasowe. Pozycja w przestrzeni społecznej jest kształtowana nie na bazie wielkości trzech typów kapitałów, ale także ich struktury oraz ewolucji w czasie. Oznacza to, że zamiast uproszczonego podziału na klasy wyższe, średnie i niższe otrzymujemy bardziej złożone pole pozycji (różne wielkości różnego typu kapitałów). Czynnikiem mediującym między pozycją klasową a przestrzenią praktyk jest habitus: zestaw dyspozycji, nabywanych na skutek powtarzalnych doświadczeń, które skłaniają do podejmowania określonych praktyk (ale ich nie determinują). Bourdieu (1985, s. 725) definiuje klasy jako „zestawy agentów, którzy zajmują podobne pozycje i którzy, będąc umiejscowieni $\mathrm{w}$ podobnych warunkach i poddani podobnym warunkowaniom, mają wszelkie szanse zyskania podobnych dyspozycji i interesów, a przez to tworzenia podobnych praktyk i przyjmowania podobnych postaw".

Uwzględniając założenia teorii praktyk, chciałabym też podkreślić, że choć codzienne działania, wybory czy sposoby myślenia są powiązane z klasowym habitusem, na ogół nie mają charakteru świadomej kalkulacji zmierzającej do podkreślenia własnej pozycji klasowej. Większość codziennych działań ma charakter „znaturalizowany”, jak pisze Bourdieu, to znaczy jest uważana za coś oczywistego i samonarzucającego się, nie zaś „wybór stylu życia”. Innymi słowy, pewne konfiguracje praktyk wydają się nam znajome, zrozumiałe, „normalne” („tak to się robi”, „to jest po prostu ładne”), inne zaś - dziwne, niezrozumiałe, obce (,jak tak można”, „ależ to brzydkie”). Oznacza to, że analiza wzorów praktyk charakterystycznych dla określonych klas społecznych nie może być zaprojektowana w ten sposób, by rodzaje podejmowanych praktyk były pojmowane jako „epifenomen struktury społecznej" (Gdula, Lewicki, Sadura 2014, s. 20). Zamiast koncentrować się na tym, jak chodzenie do teatru lub jedzenie pizzy skorelowane jest z wykształceniem i dochodem, lepiej więc poszukiwać „zasad generatywnych, nieuświadamianych reguł, wzorów klasyfikowania świata i dyspozycji ukierunkowujących wybory jednostek w wielu sferach oraz ukazania, jak są one powiązane $z$ warunkami egzystencji ludzi, jak układają się w (binarne) relacje oraz jak prowadzą do systematycznych wykluczeń, budowania barier i ustanawiania społecznych hierarchii" (Cebula 2017, s. 57).

\section{DWIE GRUPY PORÓWNAWCZE I OSIE RÓŻNIC}

W analizie przeprowadzonej na potrzeby tych rozważań wyłoniłam dwie grupy porównawcze, w których poszukiwałam podobieństw reguł, 
wzorów i dyspozycji do działania wiążących się z praktyką przyjmowania gości i odwiedzania innych. Po pierwsze, były to osoby o dość wysokich poziomach wszystkich kapitałów, zwłaszcza kapitału kulturowego i społecznego - w swoich miejscowościach reprezentowały elitę kulturalną, a ich zarobki były raczej wyższe niż przeciętne. Osoby te oznaczone są jako: Zofia, $69^{4}$ (psycholożka), Joanna, 38 (dyrektorka instytucji kultury), Agnieszka, 34 (socjolożka pracująca w instytucji pedagogicznej), Adam, ok. 40 (dyrektor instytucji kultury) oraz Jadwiga, 52 (osoba z wykształceniem wyższym, podróżniczka, obecnie przedsiębiorca). Jak widać, w relacyjnym spojrzeniu na klasy społeczne zawód nie musi być ściśle powiązany $z$ habitusem - osoba prowadząca firmę, terapeuta i dyrektor to osoby, które łączy wysoki poziom wszystkich kapitałów i, jak za chwilę wykażę, podobieństwo reguł i wzorów gościny. Po drugie, wyróżniłam osoby o niskich poziomach kapitałów, jednak niedoświadczające biedy: Karolina, 38 (sprzątaczka, wykształcenie średnie), Jolanta, 64 (gospodyni domowa, wykształcenie zawodowe), Sandra, 24 (gospodyni domowa, wykształcenie średnie), Marzena, 42 (bezrobotna, wykształcenie zawodowe) i Zbigniew, 68 (ślusarz, wykształcenie zawodowe). Dwie wyróżnione przeze mnie grupy absolutnie nie wyczerpują spektrum możliwych mozaik różnych typów kapitałów. W terminologii Mike’a Savage'a (2013) pierwszej z grup najbliżej byłoby do „utrwalonej klasy średniej”, drugiej zaś do tradycyjnej klasy ludowej. W tekście dokonuję miejscami skrótów, odwołując się do tych grup jako klasy średniej i ludowej — jednak chciałabym zastrzec, że każdorazowo mam na myśli jedynie pewne frakcje tych klas.

Szukając ogólniejszych wzorów praktyk, oparłam się w głównej mierze na charakterystyce praktyk kulturowych klasy ludowej Richarda Hoggarta (1976), także klas średnich (Bourdieu 2005), podsumowanych na polskim gruncie między innymi przez Macieja Gdulę, Mikołaja Lewickiego i Przemysława Sadurę (2014) oraz Kamila Łuczaja (2017). Na podstawie ich dotychczasowych ustalen przygotowałam zestaw osi dychotomii, aby poszukać za ich pomocą wzorów charakterystycznych dla każdej z klas. W literaturze powtarzają się takie wzory praktyk klas ludowych jak: konwencjonalność, solidarność, moralność, poświęcenie, familiarność, posłuszeństwo, nastawienie na zgodę, obfitość, sytość, konkretność, tradycyjność. Kolejnym krokiem było kodowanie danych jakościowych za pomocą programu MAXQDA. Sposób kodowania bliższy był tzw. kodowaniu a priori niż teorii ugruntowanej, ze względu na wstępne założenia dotyczące wzorów praktyk. Jednak $\mathrm{w}$ procesie kodowania zaczerpnięte $z$ literatury

\footnotetext{
${ }^{4}$ Imiona zostały zmienione, liczba oznacza wiek badanych.
} 
kategorie połączyłam w pewne ogólniejsze syndromy i uzupełniłam je nowymi kategoriami, jakie wyłoniły się z materiału badawczego. Doszłam do wniosku, że większość wzorów przypisywanych klasie ludowej można zaklasyfikować jako w pewnym stopniu reprezentujące cechy tradycyjnie rozumianej wspólnoty, natomiast wzory przeciwne wiążą się z indywidualnością i różnicą. Kwestię konwencjonalności i norm versus samodzielnego ustalania zasad uzupełniłam o opozycję: opieranie się na wzorcach ro-

\begin{tabular}{|c|c|c|c|}
\hline $\begin{array}{c}\text { Wzór A - tradycyjna } \\
\text { wspólnota }\end{array}$ & $\begin{array}{c}\text { Wzór B - indywidualność } \\
\text { i różnica }\end{array}$ & & \\
\hline I. KONWENCJONALNOŚĆ & $\begin{array}{l}\text { I. MODYFIKOWANIE ZA- } \\
\text { SAD, REFLEKSJA NAD } \\
\text { ZASADAMI }\end{array}$ & Źródło & $\begin{array}{l}\text { Różnicująca } \\
\text { réca }\end{array}$ \\
\hline $\begin{array}{l}\text { Kopiowanie wzorów rodzin- } \\
\text { nych/tradycji }\end{array}$ & $\begin{array}{l}\text { Refleksja nad wzorami/tra- } \\
\text { dycją, odcięcie od wzorów } \\
\text { rodzinnych/od tradycji }\end{array}$ & $\begin{array}{l}\text { Kategoria utworzona na pod- } \\
\text { stawie ogólnego wzorca „kon- } \\
\text { wencjonalność” }\end{array}$ & $\begin{array}{l}\text { Mocno różnicująca, ale zależ- } \\
\text { na też od wieku/pokolenia }\end{array}$ \\
\hline $\begin{array}{l}\text { Niechęć do eksperymentów, } \\
\text { znane, „normalne” rozwiąza- } \\
\text { nia }\end{array}$ & $\begin{array}{l}\text { Eksperymentowanie, „coś } \\
\text { nowego”, zainteresowanie } \\
\text { innością }\end{array}$ & $\begin{array}{l}\text { Kategoria utworzona na pod- } \\
\text { stawie ogólnego wzorca „kon- } \\
\text { wencjonalność" }\end{array}$ & $\begin{array}{l}\text { Różnicująca, ale mocno za- } \\
\text { leżna od wieku/pokolenia }\end{array}$ \\
\hline $\begin{array}{l}\text { Scena i kulisy; biała i czarna } \\
\text { izba }\end{array}$ & Pomieszanie sceny i kulis & $\begin{array}{l}\text { Kategoria utworzona na pod- } \\
\text { stawie ogólnego wzorca „kon- } \\
\text { wencjonalność” }\end{array}$ & $\begin{array}{l}\text { Różnicująca, jednak w spo- } \\
\text { sób nieoczywisty }\end{array}$ \\
\hline $\begin{array}{l}\text { Ścisły podział kobiece-mę- } \\
\text { skie }\end{array}$ & $\begin{array}{l}\text { Mieszanie się podziałów ko- } \\
\text { biece-męskie }\end{array}$ & $\begin{array}{l}\text { Kategoria zaczerpnięta } z \text { li- } \\
\text { teratury przedmiotu (m.in. } \\
\text { Bourdieu 2005) }\end{array}$ & $\begin{array}{l}\text { Mocno różnicująca niezależ- } \\
\text { nie od wieku }\end{array}$ \\
\hline $\begin{array}{l}\text { II. FAMILIARNOŚĆ, PO- } \\
\text { UFAŁOŚĆ }\end{array}$ & II. NIEFAMILIARNOŚĆ & & \\
\hline $\begin{array}{l}\text { Więzi oparte na bliskości } \\
\text { przestrzennej i więziach po- } \\
\text { krewieństwa }\end{array}$ & $\begin{array}{l}\text { Więzi oparte na podobień- } \\
\text { stwie stylu życia, zaintereso- } \\
\text { wań }\end{array}$ & $\begin{array}{l}\text { Kategoria utworzona na pod- } \\
\text { stawie ogólnego wzorca „fami- } \\
\text { liarność" }\end{array}$ & Różnicująca \\
\hline Luz, swoboda, żart & Maniery, powściągliwość & $\begin{array}{l}\text { Kategoria zaczerpnięta } z \text { lite- } \\
\text { ratury przedmiotu (Bourdieu } \\
2005 \text { ) }\end{array}$ & $\begin{array}{l}\text { Nie różnicująca, charak- } \\
\text { terystyczna dla obu środo- } \\
\text { wisk }\end{array}$ \\
\hline $\begin{array}{l}\text { Nastawienie na zgodę. } \\
\text { Skromność, „nie wywyższać } \\
\text { się”, solidarność grupowa }\end{array}$ & $\begin{array}{l}\text { Zgoda na różnice zdań. Od- } \\
\text { różniać się, zaimponować } \\
\text { innym }\end{array}$ & $\begin{array}{l}\text { Kategoria zaczerpnięta } z \text { lite- } \\
\text { ratury przedmiotu (Bourdieu } \\
\text { 2005, Hoggart 2006) }\end{array}$ & $\begin{array}{l}\text { Nie różnicująca, charak- } \\
\text { terystyczna dla obu środo- } \\
\text { wisk, ale różnica w narracji } \\
\text { uzasadniającej }\end{array}$ \\
\hline $\begin{array}{l}\text { Poświęcenie, by zyskać uzna- } \\
\text { nie grupy. Potrzeby innych. } \\
\text { Roztaczanie opieki }\end{array}$ & $\begin{array}{l}\text { Niezgoda na poświęcenie. } \\
\text { Własne potrzeby. Brak opieki } \\
\text { — pozostawianie wolności }\end{array}$ & $\begin{array}{l}\text { Połączenie kategorii „poświęce- } \\
\text { nie” (Bourdieu 2005, Hoggart } \\
\text { 2006) z opozycją „opieka, } \\
\text { asymetria vs. brak opieki, sy- } \\
\text { metria” z badań własnych }\end{array}$ & Silnie różnicująca \\
\hline „Po prostu być" & Działać celowo & $\begin{array}{l}\text { Kategoria zaczerpnięta } z \text { lite- } \\
\text { ratury przedmiotu (Bourdieu } \\
\text { 2005, Hoggart 2006) }\end{array}$ & $\begin{array}{l}\text { Raczej różnicująca, niejedno- } \\
\text { znaczność, wpływ wieku/po- } \\
\text { kolenia }\end{array}$ \\
\hline III. SUBSTANCJALNOŚĆ & $\begin{array}{l}\text { III. FORMA, WYSUBLIMO- } \\
\text { WANIE }\end{array}$ & & \\
\hline Mięsność, sytość, obfitość & $\begin{array}{l}\text { Lekkość, powstrzymywanie } \\
\text { się }\end{array}$ & $\begin{array}{l}\text { Kategoria zaczerpnięta } z \text { lite- } \\
\text { ratury przedmiotu (Bourdieu } \\
2005 \text { ) }\end{array}$ & Raczej różnicująca \\
\hline $\begin{array}{l}\text { Treść zamiast formy — nie- } \\
\text { przywiązywanie wagi do } \\
\text { estetyzacji, dekoracji }\end{array}$ & Estetyzacja, dekoracyjność & $\begin{array}{l}\text { Kategoria zaczerpnięta } z \text { lite- } \\
\text { ratury przedmiotu (Bourdieu } \\
2005 \text { ) }\end{array}$ & $\begin{array}{l}\text { Nie różnicująca, charak- } \\
\text { terystyczna dla obu środo- } \\
\text { wisk, ale różnica w narracji } \\
\text { uzasadniającej }\end{array}$ \\
\hline
\end{tabular}


dzinnych versus odcięcie się od wzorców rodzinnych, szukanie nowych wzorców. Istotną opozycją jest też to, w jakim stopniu wyraźnie wyodrębniona jest granica między sceną a kulisami (Goffman 2008). Elementem opozycji familiarność-niefamiliarność okazało się też rozróżnienie między więziami opartymi na bliskości przestrzennej (sąsiedzi) i więzach pokrewieństwa a tymi opartymi na podobieństwie (stylu życia, pracy) oraz to, w jakim stopniu gospodarz roztacza opiekę nad gościem, a w jakim zostawia mu swobodę (szerzej zob. Skowrońska 2019). Wyróżniłam też kwestię luzu/żartu w opozycji do dobrych manier/powściągliwości. Przedstwione zestawienie zawiera opis ostatecznego kształtu klucza kodowego, któremu zostały nadane ogólniejsze kategorie (oznaczone cyframi rzymskimi).

W pierwszej kolumnie znajdują się wzory przypisywane klasie ludowej, w drugiej kolumnie - wzory przeciwne. Trzecia kolumna wskazuje na to, czy wzór zaczerpnięto z podanej powyżej literatury przedmiotu, czy też powstał jako rezultat analizy materiału i procesu kategoryzacji. Ostatnia kolumna wskazuje na to, czy dana dyspozycja praktyk przedmiotu okazała się różnicująca, czy nie; i czy potwierdza dotychczasowe ustalenia badaczy, czy też niekoniecznie (brak różnicowania oznacza, że - wbrew dotychczasowym ustaleniom - pewne dyspozycje nie są charakterystyczne tylko dla klasy ludowej).

Należy zaznaczyć, że wskazane różnice między grupami bywają mniej lub bardziej intensywne, a sporą rolę odegrała nie tylko kwestia wysokości kapitałów, ale też wieku. Na podstawie analiz nie można przypisywać środowiskom społecznym stałych cech — można jedynie wskazać, że istnieje prawdopodobieństwo, iż pewnego rodzaju struktura i wysokość kapitału będzie wiązać się z tendencją do pewnego rodzaju wzorów praktyk.

\section{WYNIKI ANALIZ}

I. Konwencjonalność/modyfikowanie zasad, refleksja nad zasadami

Kopiowanie wzorów rodzinnych czy odcięcie od schematów?

Spośród wziętych pod uwagę wymiarów praktyk najsilniej różnicowały dwie wyróżnione przeze mnie grupy dyspozycji dotyczących reguł i konwencji. Osoby o kapitałach na wysokim poziomie mocno podkreślały dystans wobec utartych schematów i ról wpisanych w wizyty. Dwie osoby wyznały wręcz, że nie lubią słów "gospodarz”, „gospodyni” - wydają się im one „nienaturalne”, „nie czują ich”. Jedna z nich, Agnieszka, uwa- 
ża, że ze względu na swój typ osobowości i nieumiejętność gotowania nie potrafi wejść w rolę gospodyni — czuje, że wymogi tej roli nie są do niej dopasowane.

Bo te ostatnie urodziny się ostatecznie okazało, że sa u teściów, a jakieś wcześniejsze zrobitam tutaj. No i ten stót tam przeniesiony. I to $w$ ogóle tak kurczę, jakoś tego kompletnie nie czułam, te talerze... nie, kompletnie tego nie czuję. Dla mnie byto to jakoś nienaturalne. Nie wiem, $z$ czego to wynika. Ale to byto, no wtaśnie, nienaturalne. Może dlatego, że się nie dzieje. Gdyby się działo częściej i to bytby standard. Ale to się dzieje raz na jakiś czas $i$ to dla mnie nie jest po prostu naturalne. Ja jako ta gospodyni, która przynosi to jedzenie ten obiad... o Jezus. W ogóle tego nie czuję. [...] nie ma tej naturalności, to nie jest moja rola po prostu [...]. Ja się muszę do tego do tej roli wbić. Która tak przynosi i gospodarzy, ale to jest sztuczne, niefajne. (Agnieszka, 38)

Agnieszka wielokrotnie używa słowa „naturalność”, które wydaje się kategorią bardzo ważną dla osób o wysokich poziomach kapitałów. Tym, co kluczowe w kontekście refleksji nad konwencjonalnością zachowań, jest jednak przede wszystkim dystans do roli. Nosząc dla gości talerze, Agnieszka nie czyni tego machinalnie, automatycznie (na zasadzie „tak to się przecież robi”), ale zaczyna podważać sens i formę tej czynności. Podobny rodzaj dystansu przejawia czterdziestoletni mężczyzna, Adam, osoba $z$ tego samego towarzyskiego kręgu. Uznaje, że słowo "gospodarz" jest nieadekwatne do opisu jego i jego przyjaciół. Co prawda odwiedzają się nawzajem, jednak są w jego odczuciu po prostu „ludźmi”, „przyjaciółmi" - sytuacja gościny nie narzuca im (w jego ocenie) żadnych wymogów związanych $\mathrm{z}$ rolą gospodarza.

Znaczy śmiać mi się chce $z$ tych „gospodarzy”, bo to sa ludzie. Z tych moich przyjaciót to nie są dla mnie... Znamy się na tyle dobrze, że każdy wie, kto jest. (Adam, ok. 40)

Adam również odwołuje się do opozycji sztuczność-naturalność. Bycie gospodarzem jest rolą - Adam obawia się, że można tak skupić się na jej odgrywaniu, iż pozostałe aspekty osoby (wszystkie wiązki ról, aspekty osobowości, odczuwane jako „prawdziwe ja”) zostają przez tę rolę zdominowane.

To jest szacunek dla drugiej osoby, u której się gości. Ale też mówię, żeby nie być sztucznym. To się wyczuje $i$ to będzie rzutowało na kolejne chwile tego goszczenia się. No, bo myślę, że każdy gospodarz wyczuje, że coś jest nie tak, nie. Czy to z naszej strony, być może z jego strony. A tego byśmy nie chcieli. (Adam, ok. 40)

Według Adama i Joanny naturalność przejawia się w tym, że reguły gościny nie różnią się znacząco od reguł codziennego życia rodzinnego - 
$\mathrm{w}$ ich oczach konwencja gościny, polegająca między innymi na przygotowaniu scenografii i rekwizytów gościny (porządki, jedzenie, zastawa), rytuałach troski, pracy emocjonalnej, jest „sztuczna”. Oboje definiują swoje praktyki poprzez odrzucenie schematów i konwenansów, urefleksyjniając to, na czym gościna na ogół polega, i świadomie odcinając się od tych wzorców.

U moich teściów wyglada to tak, że wszyscy siedza za stołem $i$ - co jest dla mnie nie do przyjęcia - teściowa ciagle zapiernicza. (Adam, ok. 40)

Lubią też podkreślać twórczy i spontaniczny charakter swoich spotkań.

No, to nie jest, że jak już się spotykamy, to musi być na przyktad jakiśschemat, że jest. Nie. Czasami go po prostu kompletnie nie ma, nie? No wystarczy, że, nie wiem, ktoś instrument weźmie. Czy nie wiem, czy scenariusz zmienia, jak mieliśmy zaplanowane urodziny Agi i ognisko mieliśmy zrobić. Pogoda była taka byle jaka, więc świeczki, ptytę, drewienka u... W przedpokoju ułożone. I była gitara, i siedzieliśmy przy ognisku. Tylko to byto ognisko domowe. Ziemniaki w piekarniku piekliśmy. (Joanna, 38)

Nie oznacza to jednak, że osoby o niższych kapitałach działają w sposób bardziej schematyczny, a te o wyższych - mniej. Mam raczej na myśli to, że osoby o wysokim poziomie kapitałów mogą mieć tendencję do tego, by wykazywać większą refleksję dotyczącą konwencji, świadomie się wobec niej dystansować i podkreślać, że zachowują się odmiennie, porównywać różne modele gościnności i starać się umieścić swój wśród nich. Tak czyni 52-letnia Jadwiga, która sporą część życia mieszkała w Grecji i krytycznie podchodzi do rodzimej gościnności, z niechęcią komentując zbytnie skupienie na formie:

U nas [w Polsce] wszyscy sq skupieni by ten stót pięknie wyglądat, wszystkie te potrawy tak do zdjęcia gotowe. Tam tak nie ma. U nas nie możesz pójść w święta do kogoś jak nie jesteś odświętnie ubrany, nie wypada. Czy do kościoła. (Jadwiga, 52)

Również 69-letnia Zofia dystansuje się od roli gospodarza, mówiąc:

Ja się dobrze czuje jako gość, właściwie to widać jakby przy wejściu. Ja nie lubię, jak ktoś mnie chce tak bardzo gościć, jest taki nadmiernie zapraszajacy. (Zofia, 69).

Wypowiedzi osób z klasy ludowej, w odróżnieniu od wszystkich dotychczas przytoczonych przykładów, wskazują raczej na to, że konwencja gościny - w takiej formie, w jakiej jest znana - nie jest kontestowana. W klasie ludowej (o czym będzie jeszcze mowa) gościna przybiera najczęściej dwie formy: albo spontanicznych, niezobowiązujących wizyt (których często nie definiuje się jako wizyty, goszczenia - „po prostu sąsiadka wpadła"), albo zapowiedzianych imprez — imienin, urodzin i innych uroczystości, które wymagają odpowiedniej oprawy. Obie formuły goszczenia 
mają swoje niepisane reguły, których zwykle się nie podważa. Idąc na imieniny, urodziny czy parapetówkę należy się uroczyście ubrać, wziąć prezent, zapytać gospodynię „czy pomóc?”, a następnie zasiąść przy stole. Zbigniew mówi, że „nie iść z gołymi rękami” to powszechnie obowiązujący zwyczaj, podobnie jak założenie garnituru na uroczystą wizytę:

[...] tę kawę, bombonierę, coś tam jeszcze się kupi, nie? Tak żeby jakieś owoce, pomarańcze czy coś... Tak żeby nie z gotymi rączkami jechać. [...] To jeszcze u nas taki zwyczaj... Nie widze, że tylko my, ale to tu wszyscy tak już.

$[\ldots]$

B: A to na takie imieniny do kolegi to trzeba $w$ garniturze iść? Czy...?

R: No raczej tak. (Zbigniew, 68)

Marlena podkreśla, że idąc w gości, zawsze ma drobny podarek dla gospodarzy i tego samego oczekuje w zamian:

Jak do mnie przychodzi, tak? To jest mój gość, dobry gość, no... no lubię jak ten gość przyjdzie i na przykład coś przyniesie. Lubię. Czy tam dla dziecka cukiereczek, czy tak coś dla mnie, raz kiedyś jakąś kawę, bo ja tak robię. (Marzena, 42)

Sandra, poproszona o zrekapitulowanie ostatniej wizyty, opowiada o parapetówce ciotki swojego męża. Goście siedzieli przy stole i jedli liczne potrawy przygotowane przez gospodynię. Sandra uznaje taką formę spotkania za oczywistą, nie podważa jej. Zakłada, że zorganizowanie parapetówki dla rodziny jest koniecznością. Co więcej, należy gości zaprosić „na świeżo”, wkrótce po zakupie mieszkania — inaczej mogliby poczuć się urażeni:

Ostatnio ja byłam goszczona u cioci męża. To była parapetówka. Wybudowali się i zaprosili, żeby obejrzé́. Posiedzieliśmy przy stole, ciotka nagotowała dużo jedzenia [...]. Jak jeszcze świeżo byto, to zrobili ta parapetówkę. Wiadomo, że teraz święta, to by się przeciagnęto. Niektórzy to mogliby mieć pretensje, że tyle czasu, a oni jeszcze nie zaprosili. Ja tak nie mam, ale niektórzy mają. (Sandra, 24)

Dla Sandry oczywiste jest też to, że krzątającej się gospodyni należy pomóc - takie reguły wyniosła $z$ domu. W przeciwieństwie do Adama czy Agnieszki nie zastanawia się nad tym, czy mówienie „gospodyni” pasuje do pełniącej tę rolę osoby, czy brzmi sztucznie lub śmiesznie. Sandra odwołuje się do normy dobrego wychowania i do rodzinnych wzorców:

Jeśli gospodyni sama w kuchni robi, to zapytajmy, czy nie pomóc. To jest takie dobre wychowanie. Też z domu musimy wynieść, żeby się dobrze gościć. (Sandra, 24)

Podkreśla też, podobnie jak Zbigniew i Marlena, że należy przestrzegać zasady o nieprzychodzeniu w gości „z pustymi rękami”:

R: Nie zdarzyto mi się na urodziny czy parapetówki przyjść bez prezentu. 
B: Czyli to jest taki rytuat?

R: Tak, zawsze kupuję to samo. Stoiki na kawę, cukier, makę itp. Wszyscy są z tego zadowoleni. (Sandra, 24)

Przedstawione charakterystyki wzorów osób reprezentujących zróżnicowane poziomy kapitałów komplikują się jednak, gdy uwzględnimy kwestię pokoleń. Kiedy osoby o wysokich poziomach kapitałów spotykają się ze znajomymi ze swojego środowiska, reguły bywają kontestowane, jednak kiedy gościna dotyczy osób z rodziny, ze starszego pokolenia (rodziców, dziadków, cioć), takie osoby jak Adam czy Agnieszka zarzucają swój elastyczny model gościny na rzecz tradycyjnych wzorców. Nie znając pozycji klasowej rodziców Adama i Agnieszki, możemy jedynie przypuszczać, że pozycja ich dzieci jest wynikiem awansu, co tłumaczyłoby rozbieżności wzorców. Inna możliwość jest taka, że w poprzednim pokoleniu pewne reguły były bardziej powszechne i mniej zależne od pozycji społecznej:

Jeśli to jest taka domówka, nazwijmy to, ale taka z rodzina, to zazwyczaj jest jakiś tam gospodarz. To jest, powiedzmy, moja mama czy teściowa, czy to jest ktoś, kto gdzieś tam się pojawia $w$ kuchni $i$ to on donosi. Ale jeśli to jest spotkanie znajomych, dobrych znajomych, no to tak jak wcześniej wspomniałem: nie ma czegoś takiego, że ja nie mogę zajrzeć do lodówki. To jest na zasadzie: a co masz w lodówce? Aaa! Mmm! Dobre. A, to, to! Tak to wyglada. (Adam, ok. 40)

Ponadto osoby młodsze i o niższym poziomie kapitałów, takie jak Sandra i Marzena, choć nie podważają ani nie krytykują reguł gościny, zaczynają wprowadzać nowe reguły niezobowiązujących spotkań ze znajomymi ze swojego pokolenia. Na przykład Marzena gromadzi wokół siebie grono koleżanek i ich sióstr, kuzynek oraz przyjaciółek, które zamiast gościć się w domach, odwiedzają po kolei wszystkie nowe, nieznane sobie miejsca w okolicy: knajpki, kręgielnię, basen:

Dzwonię do kilku babeczek, no i mówię, dziewczyny stuchajcie idziemy na kręgielnię $w$ tym roku? Zamówitam dwa tory na dwie godziny. No to $w$ tamtym roku miatam, mówię, szesnaście chętnych. [...] I byliśmy już na basenie [...], byliśmy po różnych knajpach tutaj, byliśmy po pizzeriach. W tym roku nie wiem, też muszę coś wymyślić. $W$ tym roku nie wiem, na razie nic się nie otworzyło, nie wiem, ale może [pojedziemy] do [nazwa miasta] [...] (Marzena, 42)

Sandra podkreśla, że baby shower, na którym była, jest imprezą „modną” i „nietypową":

Ostatnio to ja bytam goszczona na takiej imprezie dla mnie, baby shower. To zaczyna być modne i to była taka nietypowa impreza. Pierwszy raz bytam na takiej nietypowej imprezie. 
Eksperymentowanie czy niechęć do eksperymentów?

Czynnik pokoleniowy okazał się istotny także w kolejnym wymiarze zróżnicowania, jakim jest chęć lub niechęć do eksperymentowania. W odniesieniu do gościny ten wymiar najlepiej można zaobserwować w rozmowach dotyczących kulinariów. Najwięcej niechęci wobec eksperymentów w tym zakresie zawierały wypowiedzi osób starszych o niskich kapitałach: Jolanty (64) i Zbigniewa (68). Oboje stanowczo opowiadają się za tradycyjną kuchnią. Jolanta wprost komunikuje, że nie „wymyśla” — gotuje „normalnie”:

Z tym, że ja nie wymyślam tė̇ żadnych krewetek, żadnych tych, tych kalmarów, nie. Ja jestem tradycjonalistka i u mnie obiad normalnie. Musi być rosót, czy tam pomidorowa, nie. No jakieś tam kurczak, dewolaje moga być. (Jolanta, 64)

Przeciwnikiem eksperymentów jest także Zbigniew. Soki przygotowuje sam, z owoców z ogrodu - woli je od "nowoczesnych”, jak je określa, „z kartonu”:

Z winogron też robimy sok. Zawsze przekręcimy i ten sok i później do obiadu na przykład podaje się tam, na przykład jakaś impreza rodzinna jest, to też podajemy na zapitkę [śmiech]. No bo niektórzy, szczególnie młodzi teraz, to oni na to nie patrzą. Oni raczej wola te nowoczesne takie, te $z$ kartonu, te soki tego... A ja na przyktad wolę swoje, nie? (Zbigniew, 68)

Zbigniew nie jest przekonany do nowych kulinarnych trendów. Nie przepada za tendencją do serwowania większej ilości sałatek — od lat jest miłośnikiem jednej, tradycyjnej sałatki jarzynowej. Nawet sałatki warstwowe, jakie robi jego żona - obecne na polskich stołach jeszcze w PRL - są przez niego interpretowane jako kulinarne nowinki.

R: A teraz, wie Pani, tak szczerze mówiąc tak jak my na przykład mieliśmy to spotkanie, czy nawet jak się idzie do kogoś to przeważnie to tak bywa... Zawsze albo 3-4 rodzaje sałatek. Już teraz zwiększyto się. Ja tam tylko jedna sałatkę lubię to... [śmiech] jedna jem.

B: Którą? Tę tradycyjną? [śmiech]

R: Tę tradycyjna. A tam jakieś warstwowe sałatki, a jakieś tam, wie Pani, jeszcze... Namieszali tam wszystkiego. Lubiq... Żona na przykład wszystkie sałatki — byłoby pięć, ona by pięć zjadta. Lubi to, a ja tam jedna tylko, tradycyjnie. (Zbigniew, 68)

W młodszym pokoleniu klasy ludowej pojawia się odmienny wzorzec. Marzenie (42) - tej samej, która z grupą koleżanek zwiedza nowe miejsca rozrywki w okolicy - sprawia radość i satysfakcję, gdy „zabłyśnie nowością". Co prawda, większość przygotowywanych przez nią potraw jest tradycyjna (żurek, karkówka, zupa gulaszowa, kiełbasa), jednak od czasu 
do czasu lubi poeksperymentować i zaserwować modną potrawę. Ostatnim razem przygotowała sałatkę ze szpinaku:

Tak że taka... żeby zabtysną́ nowościa, to była ta galaretka i ten szpinak. Ten szpinak to najbardziej to ich powalit wszystkich. I tu potożytam i nikt nie je. Jak... no to tylko ten szpinak jedli. Żadnych sałatek, nic, wszystko przebiło... szpinak przebit wszystko. (Marzena, 42)

Marzena podjęła ryzyko. Początkowo eksperyment nie spotkał się z uznaniem otoczenia. Goście patrzyli podejrzliwie: „co ty jesz, liście?” Ostatecznie, gdy odważyli się spróbować, Marzena triumfowała — odniosła spektakularny sukces kulinarny.

No to wziętam zrobiłam szpinak z takim sosem miodowo-cytrynowo-pikantnym. Tak. Mam taki przepis. No i oni tak się patrza na mnie — liście szpinaku wysypane i tym polane i do tego prażone migdaty. Się patrza i nikt tego nie je. No to ja wzięłam sobie, jem, tak patrza — a co ty jesz, liście? Nie, ja mówię, no spróbuj. Jezus Maria! Dobrze, że ja dwie paczki kupitam, bo chyba z sześć razy im to robitam, tak im to smakowato, nie? (Marzena, 42)

Dla osób o wysokich poziomach kapitałów eksperymentowanie było bardziej istotne i znacznie bardziej oczywiste. Zofia ustaliła wręcz ze swoim bratem, że kiedy się spotykają, zawsze gotują coś całkiem nowego eksperymentowanie sprawia im przyjemność.

$Z$ bratem mieliśmy taka niepisana umowę, że zawsze musi być jakaś nowa potrawa. Nigdy nie wypowiedzieliśmy tego głośno, ale tak byto. Oboje jesteśmy tacy, że lubimy nowości. (Zofia, 69)

Fanką nowości okazała się też przyjaciółka Zofii, dla której gotowanie, a zwłaszcza wynajdywanie nieznanych przepisów, to pasja:

[...] ona uwielbia piec, gotować i eksperymentować. I czasami: „ach, nie miałam co robić i znalazłam taki przepis" i u niej często jest coś do próbowania. (Zofia, 69)

Pół żartem, pół serio Zofia postanowiła raz przygotować ośmiorniczki, które po politycznym skandalu w Polsce stały się synonimem wystawności. Zofię zaciekawiły - postanowiła sprawdzić, jak smakują, kiedy wypatrzyła je w dyskoncie:

Byty moje imieniny akurat $w$ okresie tych afer $z$ ośmiorniczkami. Pojawity się te ośmiornice w Biedronce, a ponieważ ja lubię testować takie nowe rzeczy, to mówię, że może zrobię te ośmiorniczki. (Zofia, 69)

Radość z gotowania ma też Joanna, szukająca pomysłów w internecie. Deklaruje, że nie boi się sięgania po nieznane przepisy:

Mam stronę Kwestia Smaku, na której sobie korzystam tak najczęściej. I rzeczywiście, nie wiem, no na przykład wczoraj byty szaleństwa $z$ dyni, więc wpisałam sobie dynie 
izastanawiałam się, co z niej po prostu zrobić, nie. I nie ma czegoś takiego, że pierwszy raz, że się boje, nie. Próbuję. (Joanna, 38)

Jadwiga, której mąż jest Grekiem, lubi przygotowywać potrawy inne niż polskie:

Specjalizujemy się z mężem w innych potrawach niż polskie. Znacznie wcześniej planujemy. Jedna przyjaciótka jest wegetarianka, więc zawsze przygotowujemy to menu, żeby wszyscy byli zadowoleni. Teraz będziemy sobie robity optatek, to zrobimy pierogi ze szpinakiem. To jest ważne, żeby zawsze kogoś czymś fajnym ugościć. Sama hoduje baktażany i robię musakę. (Jadwiga, 52)

W żadnej wypowiedzi osób $z$ wysokimi poziomami kapitałów nie pojawił się wątek niechęci do eksperymentów czy przywiązania do wypróbowanych rozwiązań. Przeciwnie - eksperymentowanie i nowość jawiły się raczej jako punkt honoru.

\section{Scena $i$ kulisy?}

Jak już wspomniałam wcześniej, dla klasy ludowej charakterystyczne są dwa bardzo odmienne typy reguł dotyczących goszczenia: niezobowiązujące „wpadanie” sąsiadów i rodziny oraz imprezy — proszone przyjęcia z jakiejś okazji. Jolanta wyjaśnia różnicę między tymi formułami goszczenia, tłumacząc, że regularne odwiedziny sąsiadki nie wiążą się z żadnymi przygotowaniami, w przeciwieństwie do uroczystości takich jak imieniny:

[Gdy wpada sąsiadka to] tylko kawa. Kawa. Nieraz jak ma jakieś tam ciasto, nie, czy coś, to tak. A tak nikt nie, nie, nie. Chyba że jak jakaś tam impreza jest, nie? Jakie imieniny, czy coś, no to wtedy szykujemy się, nie? Ona, czy ja, nie? No, to już tak sie szykujemy. Jest tam zakaska i jest do zakaski, nie? (Jolanta, 64)

Również Zbigniew rozgranicza niezobowiązujące „wpadanie” od imprezowego szykowania. W domu Zbigniewa obowiązuje reguła białej i czarnej izby: czarna izba („pokój zwykły”) to miejsce rozgrywania się codzienności, podczas gdy biała izba („gościnny”) jest miejscem zarezerwowanym na święta i uroczystości.

R: W każdym bąź razie, jak ktoś do nas wpadnie, bez zapowiedzi, bez niczego to mamy taki pokój, wie Pani, zwykty. Tam córka przeważnie urzęduje, to tam usiadziemy i tam przyjmujemy, nie? [...]

B: A ten na takie imieniny mi chodziło, to jest taki większy, tak? Na takie okazje.

R: Tak, tak, ten to jest taki gościnny, jak to mówiq... (Zbigniew, 68)

Wcześniej przywoływane wypowiedzi respondentów z klasy ludowej dotyczyły raczej uroczystości, urodzin, imienin, rocznic, chrzcin. Codzienne zaglądanie sąsiadki na ogół nie jest bowiem definiowane jako wizyta 
(„po prostu wpadł po drodze”) — w związku z tym jest rzadziej omawiane w kontekście goszczenia. Bycie gościem i gospodarzem to role kojarzące się z proszonymi imprezami. Obowiązuje wówczas wyraźne rozdzielenie sceny od kulis: gospodarze przygotowują scenę i rekwizyty, przyjęcie odbywa się w pokoju dziennym („dużym pokoju”), nigdy zaś — w kuchni. Przed przyjściem gości wszystko jest przygotowane. Mężczyźni rozstawiają stoły, przynoszą dodatkowe krzesła. Dzieci pomagają nakrywać. Gospodynie „nie wychodzą z kuchni”, szykując mięsa, sałatki i ciasta. Z kolei po przyjściu gości akcja przenosi się do „dużego pokoju” (na scenę), do którego tylko donosi się jedzenie lub napoje. Niczego nie szykuje się przy gościach. Gospodyni stara się tak zorganizować swoją pracę, by podczas przyjęcia usiąść przy stole ze wszystkimi.

[...] przed tymi imprezami to żona już od środy z kuchni nie wychodzi [śmiech]. Szykuje jedzenie! Tylko żona ma taki zwyczaj, że ona naszykuje. I tych sałatek! Tego wszystkiego! No mnóstwo tego jedzenia. I jak przyjda goście to od razu na stót wszystko postawi i siada z gośćmi siedzi, nie? (Zbigniew, 68)

No, zreszta jak się spodziewam gości, czy coś, to ja sobie wszystko kroje, czy coś szykuję prędzej. I do lodówki daje, nie, czy coś. A później przychodza. No to ja stawiam, żeby to już byto uszykowane, nie. Później najwyżej coś tam na gorąco, no to w międzyczasie, nie. A tak staram się zawsze przyszykować wcześniej, żeby goście nie czekali, żeby nie, nie, nie patrzeli mi na ręce [...] (Jolanta, 64)

Reguły dotyczące codziennego przyjmowania sąsiadów i rodziny są skrajnie odmienne. Gość przychodzi bez wcześniejszego zapowiadania się, a jego wizyta nie wiąże się z żadnymi przygotowaniami. Często są to pogaduszki kobiet $\mathrm{w}$ takich godzinach, w których są same $\mathrm{w}$ domu (np. przed południem). Zdarza się, że gospodyni podczas wizyty gotuje, prasuje czy wykonuje innego rodzaju prace domowe. Sąsiadce czy siostrze zaproponuje kawę, ewentualnie coś słodkiego, jeśli ma (ale raczej nie jest to wymagane ani oczekiwane). Niezobowiązująca wizyta może też polegać na popołudniowym wypiciu piwa z sąsiadem (bratem, szwagrem, kuzynem) - w domu lub na podwórzu/przed domem. Tego typu wizyty nigdy nie wiążą się z zaproszeniem na obiad czy kolację - co jest $z$ kolei charakterystyczne dla niektórych frakcji klas średnich - które „bywają”, a nie „wpadają" (zob. Hanson 1999; Bourdieu 2005).

Sasiad wychodzi na balkon, gadka szmatka, podaja sobie nawzajem piwka, a za chwile już schodza na dót. Sąsiadka przyniesie coś, ja wyciagnę coś i to tak spontanicznie wszystko się dzieje. (Karolina, 38)

To znaczy się, tak, o tak, nieraz, nie? „Chodź na kawę”, nie? Albo ja z balkonu, ona idzie ze sklepu, to ja mówię: „No chodź na kawę!” „No dobra, zaraz przyjdę”. Albo 
ja nieraz jestem tam $w$ klatce, bo klucz od suszarni bierzemy, tam pani się zajmuje, a ona mieszka na drugim piętrze. No to ja idę, pukam [odgłos pukania] „Cześć Marysia, przyszłam, nie?” "No to siadaj, zrobię kawę taka”, nie? (Jolanta, 64)

Osoby z wysokimi poziomami kapitałów raczej nie różnicują $\mathrm{w}$ ten sposób formuł spotkań. Jak wspomniałam wcześniej, znacząca zmiana konwencji następuje wówczas, gdy zapraszając rodziców i inne osoby ze starszych pokoleń rodziny, gospodarze dostosowują się do ich reguł i roztaczają nad nimi większą opiekę niż wobec goszczonych przyjaciół. Jednak zasadą przenikającą większość spotkań, i tych bardziej codziennych, i tych odświętnych, jest brak podziału na scenę i kulisy, czarną i białą izbę. Obojętnie, czy znajomi wpadają bez okazji, czy też na urodziny, przyjmowani są w tej samej przestrzeni (zarówno w kuchni, jak i w pokoju, a często $\mathrm{w}$ dość powszechnym $\mathrm{w}$ tym środowisku salonie $\mathrm{z}$ aneksem kuchennym) i na ogół coś się wspólnie je — przy czym coraz bardziej popularną praktyką jest gotowanie razem $z$ gośćmi.

Goście już przyszli na te imieniny, a ona mi w kuchni jeszcze doprawita, bo wiedziała, jak to zrobić. To sa tego rodzaju rzeczy, że wchodzi się za gospodynia do kuchni $i$ sie gada. (Maria, 69)

Tak, można, taka jest wysepka, więc możemy tam z każdej strony sobie gdzieś tam i tu gotować. Więc to jest no fantastyczne miejsce do gotowania, więc wtedy sobie razem pi pi... Coś tam robimy, pichcimy. No, ale tak jak teraz, no siedzieliśmy, niby jedna osoba robi, a druga obiera, trzecia coś tam, trzecia coś tam, no każdy coś tam robit i potem, nie wiem, zwykłe podpłomyki, pastę do tego i każdy gdzieś tam, no ten, watkowat, ten ucierał, ten ścierat, więc i... Nie wiem, jakoś tak to fajnie. (Joanna, 38)

Ale fakt faktem, że jeśli przychodzimy do znajomych, to zawsze jest coś do jedzenia. Staramy się, bo lubimy jeść. I to nie jest pizza zamówiona w pizzerni, tylko staramy się gotować [...] nieraz nam się zdarza gotować wspólnie (Adam, ok. 40)

\section{Podział męskie-kobiece czy mieszanie podziałów?}

Kwestia ról płciowych mocno odróżnia od siebie światy osób z kapitałami na niskim i wysokim poziomie. W klasie ludowej płeć jest zazwyczaj ściśle przypisana do elementów roli gościa i gospodarza. Odzwierciedla to zwłaszcza konwencja imprezy, choć nie tylko. Codzienne, niezobowiązujące „wpadanie” odbywa się w osobnych światach mężczyzn i kobiet. Mężczyźni raczej pogadają przy płocie lub wpadną po południu na piwo, kobiety wpadną do siebie na kawę. 
Ale żona na przykład idzie na kawę, bez niczego i tam siedza godziny, sobie plotkuja (Zbigniew, 68)

Sąsiadki idą wprost do kuchni, gdzie gospodyni, pijąc kawę, będzie mogła jednocześnie się krzątać. $W$ jednym $z$ wywiadów także badaczka została zaproszona do kuchni, by informatorka mogła przygotowywać $\mathrm{w}$ tym czasie obiad. Światy mężczyzn i kobiet są zazwyczaj ściśle rozdzielone. „Wpadanie” nie obejmuje modelu wpadania pary do innej pary. Podczas imprez - a więc drugiej formuły spotkań — podział płciowy również jest bardzo wyraźny. Zwykle żywnością zajmują się kobiety („nie wychodzą z kuchni”), mężczyźni - alkoholem (kupnem bądź samodzielną produkcją, a następnie troszczeniem się o to, czy goście mają pełne kieliszki). Część dotyczących goszczenia wywiadów z mężczyznami o niskich poziomach kapitałów wręcz zdominował temat alkoholu. Na przykład Zbigniew kwestie męskości i alkoholu wiąże na trzy sposoby. Po pierwsze, kilkakrotnie wspomina, że idąc $\mathrm{w}$ gości bierze butelkę alkoholu, podczas gdy żona — „bombonierę" lub owoce („te swoje drobiazgi”):

Bierze się na parę połówkę, a tam żona tam swoje, zawsze jakieś tam drobiazgi, stodycze czy coś tam zawsze, pomarańcze, czy tam inne rzeczy, bombonierę jakaśs. I tak wtaśnie, to, to takie imieninowe sprawy, nie? (Zbigniew, 68)

Po drugie, opowiada o „twardości” niektórych znanych sobie mężczyzn, wypijających duże ilości wysoko procentowych napojów:

[...] spotykałem się z takimi gośćmi, jeszcze tam na wsi mieszkaliśmy. To byli tacy chyba twardzi ludzie [śmiech], że normalnie pił wódkę, popijat piwem! I jak postawili wino, to $i$ wino pił. I nic mu nie byto [śmiech] (Zbigniew, 68)

Po trzecie, wspomina o uzupełnianiu kieliszków gości jako zajęciu typowo męskim:

B: A to Pan jest odpowiedzialny, tak? Za polewanie.

R: Tak, zawsze albo ja albo czasami syn.

B: Aha, czyli to takie męskie zajęcie?

R: Tak, tak. To jest męskie zajęcie. (Zbigniew, 68)

Kwestie ścisłego rozdziału płci widoczne są też w opowieściach Karoliny i Sandry. W ich domach podczas imprez rozmowy toczą się w dwóch światach: kobiecym i męskim. W świecie kobiet rozmawia się o domu i rodzinie, w świecie mężczyzn - o pracy i samochodach. Trzeba jednak zaznaczyć, że w opowieści Klaudii widać próbę pogodzenia dwóch światów i znalezienia wspólnej płaszczyzny porozumienia.

R: Gadamy. To jest takie miasto, że wszyscy siebie znaja, sąiad z mężem w jednym zakładzie pracuja, więc sa rozmowy o tym, co się tam dzieje. Opowiadają sobie. A my 
kobiety to co? Remont córki ostatnio robiliśmy, ona też chce teraz, więc takie rozmowy o dzieciach, remontach...

B: A faceci o czym gadaja?

R: No jak o czym? O samochodach! [śmiech] Pewnie jakby nas nie byto, to bytby inny temat, ale już $w$ to nie wnikam. [śmiech] (Karolina, 38)

Czasami jest niezręcznie jak $w$ trzy pary siedzimy i mężczyźni rozmawiaja o samochodach. Ale po jakimś czasie się orientuja i zmieniaja temat. (Klaudia, 24)

Opowieść Jolanty nawiązuje do opisywanego przez Zbigniewa wątku alkoholu jako sprawy męskiej, a kulinariów — żeńskiej. Gdy Jolanta idzie do siostry, pomaga jej przynosić z kuchni potrawy, mężczyźni tymczasem zajmują się piciem:

Nawet jak idę do siostry, nie, co przyjechała, to ona jest w kuchni i tam coś kroi, coś tego, bo szwagier stawia na przykład pół litra, nie? Z mężem sobie tam tego, wypija. Tylko że on, dla niego pót litra to mato [śmiech obu osób]. Bo jest wielki i gruby, ale jak dla niego mało. Bo on w Anglii nie pije, bo nie ma z kim. No to pójdę do niej, do kuchni, tego, no to ja jej pomogę ponosić, nie. Po... Po... Pomogę tam jej tego, ona kroi, tam tego. (Jolanta, 64)

W środowisku osób $z$ kapitałami na wysokim poziomie istotny wydaje się zwłaszcza kapitał kulturowy — role podczas wizyty nie są tak wyraźnie rozdawane według klucza płci. U Joanny towarzystwo dzieli się „na drużyny" (goście i gospodarze przygotowują razem jedzenie, razem sprzątają, razem robią nawet remonty), przy czym w drużynie gotującej są też mężczyźni, a w drużynie malującej ściany — kobiety:

A sypialnię podzielimy się jak zwykle, bo na przykład dzielimy się na drużyny, czyli jedna drużyna idzie do malowania, do remontu pokoju, a my na przykład, ja jestem tą osoba gotujacca też, z jej mężem, na przykład my gotujemy, a reszta na przykład, czy ktoś tam jeszcze, a reszta na przykład robi jakieś prace... Czyli każdy robi to, co lubi. Efekt jest jakiś fajny, potem siedzimy przy stole. (Joanna, 38)

Często jest tak, bo na przykład przyjaciótki mąż, [...] najbardziej też lubi gotować. I oni raczej tak wola nas zostawić w kuchni, nie. No tak jak jest jakieś tam gotowanie takie wspólne, no, o oni rzeczywiście maja dom, kt... Kuchnię, zazdroszczę. No po prostu [mąż przyjaciółki] jest $w$ ogóle architektem $i$ to gotowanie jest jego pasja, więc zaprojektowat to tak, że, że ta kuchnia takim centrum (Joanna, 38)

Mąż Jadwigi, Grek, specjalizuje się w przygotowywaniu pizzy. Agnieszka nie lubi gotować i prawie tego nie robi, a jej mąż zostaje $z$ dzieckiem, gdy ona imprezuje (jest domatorem). W tym środowisku rozmowy też raczej nie dzielą się na męskie i kobiece. Model związku jest partnerski, tematy do rozmów — najczęściej wspólne. 


\section{Familiarność/niefamiliarność}

Kolejnym wymiarem opisywanym w literaturze dotyczącej praktyk klasowych (Bourdieu 2005; Hoggart 1976) jest familiarność, często przypisywana klasie ludowej. W swojej analizie rozpatrywałam kilka aspektów tej kategorii: więzi oparte na bliskości przestrzennej i więzach pokrewieństwa, swobodę i żart, solidarność objawiającą się w niewywyższaniu się i nastawieniu na zgodę, a nie różnicę, poświęcenie na rzecz grupy i nastawienie na moralność oraz potrzeby innych, opiekuńczość, a także „po prostu bycie razem" jako dominujący sposób spędzania czasu. Co do niektórych aspektów familiarności osoby o kapitałach na wysokim i niskim poziomie wykazywały dużą zgodność, co do innych zaś - całkowitą odmienność.

Więzi oparte na bliskości przestrzennej i więzach pokrewieństwa versus więzi oparte na podobieństwie stylu życia, zainteresowań

Wzorem różnicującym dwa omawiane środowiska jest sposób doboru gości odwiedzających dom. Uniwersum gości klasy ludowej obejmuje dwie najważniejsze grupy: sąsiadów i rodzinę. Zdarzają się też przyjaciółki czy koledzy z pracy lub wojska, wydaje się jednak, że bliskość przestrzenna i więzi rodzinne są dominujące. Do żony Zbigniewa codziennie wpada sąsiadka, podobnie jak do Jolanty:

Nie no, tak, przypuśćmy, to sasiadki tak przychodza, bez żadnego zapowiedzenia, zastuka, wchodzi, kawe wypije. (Zbigniew, 68)

Marzena latem z dziećmi spędza czas na podwórku, gdzie towarzyszą jej sąsiadki i sąsiad ze swoimi dziećmi:

B: $Z$ sasiadami tutaj też pani utrzymuje kontakty, czy tak stabiej?

R: Bardzo. Tutaj [imię sąsiadki], sąsiadka, bo to my we dwie i tutaj mamy sasiada [...] A znowu tutaj na podwórku przesiadujemy, tutaj sa, mają córkę jedenaście lat, dwanaście, przepraszam $i$ synek sześcioletni. No to jak jest lato, kawka, herbatka, to siadamy z tym sześcioletnim, no [imię sąsiadki] ma doroste, ale chętnie do nas przychodzi, tak że na podwórku jest zawsze parasol rozłożony, stolik... (Marzena, 42)

Aktywna Marzena - ta sama, która organizuje wypady do kręgielni czy na basen - tłumaczy, że krąg kobiet razem z nią odkrywających rozrywki w okolicy tworzy się tak, że jej krewne czy przyjaciółki zapraszają swoje sąsiadki:

Albo siostry znajome. Ja dzwonię do siostry albo do koleżanki, a ona się pyta czy ona może wzią́ sąsiadkę, bo ja jej o tym opowiadałam $i$ ona się... ja mówię: „bierz sasiadkę". (Marzena, 42) 
Osoby o wysokich poziomach kapitału zgodnie twierdziły, że ich kontakty z sąsiadami są raczej grzecznościowe.

Nie pamiętam, u kogo bytem ostatnio $w$ domu, tak żeby pójść na kawę. U swoich sasiadów. Tak że to trochę... nawet do tych najbliższych, że tak powiem, sasiadów, się nie chodzi. Przynajmniej ja nie chodzę. (Adam, ok. 40)

Goście odwiedzający ich dom to często osoby dobrane na zasadzie podobieństwa zainteresowań i stylów życia - poznani w pracy, w organizacji pozarządowej, w zespole muzycznym lub na studiach. W ich opowieściach pojawiają się wątki: wspólnego zamiłowania do historii (Zofia), literatury (Agnieszka, Joanna, Adam, Jadwiga), muzyki (Joanna, Adam), pasji do gotowania (Adam, Joanna, Zofia).

\section{Luz, swoboda, żart versus maniery i powściagliwość}

Swoboda zachowania i zamiłowanie do żartów okazały się wzorami częstymi wśród osób zarówno o niskich, jak i wysokich poziomach kapitałów. Wyrazem tej swobody jest w dużej mierze rozluźnienie ciała pozwolenie sobie na głośny śmiech, bliskość z innymi (w tańcu, ale też przytulanie, klepanie po plecach), na swobodny strój, siadanie na podłodze. To również pozwolenie sobie na częściową utratę kontroli - na przykład przez upojenie alkoholowe. Wśród przedstawicieli starszych pokoleń swoboda wyraża się w spontanicznych śpiewach, czasem tańcach. U Zbigniewa do dziś śpiewa się podczas spotkań:

No to za zdrowie solenizanta czy solenizantki wypijemy, nie? i od razu zaśpiewamy... "Pije Kuba do Jakuba, Jakub do Michała..." [...] Czasami zaśpiewamy jakaśs piosenkę, jedna, dwie, trzy... (Zbigniew, 68)

Utrata kontroli spowodowana alkoholem (zasypianie podczas imprezy, brak możliwości koordynowania ruchów) jest traktowana pobłażliwie „czasami tak jest" - nie ma powodu, by ten fakt ukrywać, nie jest to nic wstydliwego.

R: Nie, czasami tak jest, wie Pani, że z tych gości, którzy sa zaproszeni, to się woła taryfy. Bo sa nie w stanie, żeby pójść do domu [śmiech].

B: Ale się zawoła taryfe, a nie powie „No to dobra, to już przenocuj tutaj”, tak? Raczej...

R: Nie, nie, raczej ida do domu. Bo żona zawsze trzeźwiejsza, nie? Za frak i do domu! [śmiech] (Zbigniew, 68)

Jolanta wspomina „muzykę, tańcowanie i śpiewy” z imprez w czasach, gdy była młodsza. Do teraz stałym elementem spotkań jest mocniejszy alkohol: 
$Z$ mężem sobie tam tego, wypiją. Tylko że on, dla niego pót litra to mało [śmiech obu osób]. (Jolanta, 64)

U Marzeny imprezy mają bardzo swobodny charakter, na ławkach na dworze. Zdarza się, że goście umawiają się, że przyjdą w dresach lub opatuleni:

[...] albo mówimy: stuchajcie impreza dresowa, albo im robimy grilla, że będzie potupajka, ale ubierzcie się ciepło. Wiadomo, jeszcze ze trzy koce się przy... ten, pod tytek się tam ścieli, na ławkach, nie? (Marzena, 42)

Stałym elementem spotkań są dowcipy, przekomarzanie się, rozmowy o seksie albo o kryzysie wieku średniego:

B: A o czym się rozmawia na takich imprezach?

R: No wtaśnie to... przeważnie to o pracy. O seksie. Tak, o seksie to najbardziej. Kawaty o seksie albo o tym, że choroba... nie choroba, tylko kryzys wieku średniego nas dopadt. (Marzena, 42)

Żart pojawia się też w prezentach — podobnie jak motywy seksualne (prezerwatywa, koszulka nocna) i brak skrępowania w kwestiach fizjologii. W środowisku Marzeny obowiązuje bezpośredniość i bezpruderyjność.

Za to, że ona tak jeździ tym samochodem, to my jej teraz właśnie zaczęliśmy i będziemy jutro kończyć, czerwone, normalne pudetko okleiliśmy na czerwono, krzyż biaty - apteczka samochodowa. No a w tej apteczce będzie miała koszulkę nocna, co tam już kupiliśmy, no gadżecik taki, rękawiczki, prezerwatywa, takie tam dla bajery. To wszystko będzie opisane, po co ci to będzie potrzebne, nie, ten kubeczek jednorazowy, taka mała buteleczka, takie ten... W tamtym roku siostra dostała palmę. [...]

Czasami to jest tak: wpadam do tazienki... nie, otwieram drzwi, wpadam do łazienki $i$ krzyczę przez drzwi „weź się rozgość, ja zaraz przyjdę, bo mnie natura przycisnęta”. (Marzena, 42)

Na imprezach organizowanych przez Adama, Joannę i Agnieszkę osoby należące do elity kulturalnej miasteczka - obowiązuje podobna konwencja bezpośredniości i żartu. Kiedy ktoś próbuje rozmawiać o polityce, Adam ma na to sposób - rozbraja sytuację, rzucając hasło: „Porozmawiajmy o seksie". Agnieszka podkreśla, że spotkania jej przyjaciół mają bardzo swobodną atmosferę — nikt nie przejmuje się kwestią dobrych manier, ważna jest naturalność:

Jak tam jest? Wchodzimy, witamy się oczywiście, obcatowujemy, śmiejemy, przede wszystkim jest bardzo radośnie, jest dużo śmiechu, ale my też czujemy taka swobodę, nie musimy się martwić, jesteśmy w swoim gronie i jakby to często powtarzamy, że to jest taki spokój, że my możemy powiedzieć wszystko, nie zastanawiać się, czy nie palniemy jakiegoś głupstwa. (Agnieszka, 34) 
Agnieszka uznaje, że tego rodzaju swoboda jest wręcz istotą gościnności:

Ktoś kto jest gościnny. To jest ktoś kto sprawia, że nie musimy się zastanawiać, co nam wypada, a co nie wypada. (Agnieszka, 34)

Również Jadwiga dostrzega poczucie swobody na spotkaniach swojego grona, mówiąc: „Nie ma takiej sztywności”. Joanna, Adam i Jadwiga organizują tematyczne imprezy z tańcami, na których goście przebierają się i ozdabiają dom wdług ustalonej konwencji:

Na imprezach śpiewamy, tańczymy. Jak jest karnawat to rozwieszam girlandy, przebieramy się. (Jadwiga, 52)

Adam opisuje transgresyjny charakter spotkań mówiąc, że osoby z zewnątrz mogłyby uznać jego i jego przyjaciół za szaleńców:

Gdyby nasze dzieci albo nasze pracownicy popatrzyli na nas, to powiedzieliby: wariaci. Ja ostatnio pojechatem do Australii. Ale nie fizycznie, tylko z racji tego, że oni zrobili Australię u kolegi $w$ domu. Mieliśmy samolot, miałem bilet lotniczy, miałem muzykę stamtą, miatem morze, miałem piasek, australijskie trunki, misia koala, wszystko byto. Dziewczyny byty poprzebierane jak z plaż. (Adam, ok. 40)

\section{Nastawienie na zgodę/zgoda na różnice zdań}

Trzeba powiedzieć, że wyraźna potrzeba zgody, dążenia do porozumienia i braku konfliktu była absolutnie powszechna (przynajmniej na poziomie deklaratywnych narracji) w niemal wszystkich sześćdziesięciu wywiadach, niezależnie od poziomu kapitałów. Nie dziwi zatem, że nielubianym tematem rozmów okazała się polityka jako wątek potencjalnie konfliktogenny. Adam, jak wspomniałam, rozmowy o polityce ucina natychmiast, proponując "porozmawiajmy o seksie":

I unikam, jeśli ktoś coś mówi o religii lub polityce. To sa rzeczy, których staram sie nie poruszać $w$ towarzystwie, którego dobrze nie znam. Takie minusy przychodzenia w gości. Jak ktoś próbuje, staram się wycofać albo zmienić temat: „Porozmawiajmy o seksie". (Adam, ok. 40)

Zofia deklaruje, że nie lubi „zamykania się w swoich poglądach”, jednak zarazem przyznaje, że rozmowy o polityce w swoim gronie są podejmowane dopóty, dopóki w towarzystwie nie ma osoby „z innej opcji” wówczas temat ten jest omijany w imię utrzymania spójności grupy:

Nie lubię takiego zamykania się $w$ swoich pogladach, ale też staram się nie bywać wśród ludzi, którzy nie uznaja czyjegoś zdania. Ja też potrafie powiedzieć, że ja mam rację i jej bronić. Ale jeżeli widzę, że ktoś ma inne zdanie, to się wycofuję, a nie kłócę. 
Nie lubię ludzi, którzy wiedza, że to się tak skończy, a dalej drą̇̇a. [...] Nawet poglady polityczne mamy podobne $w$ większości. Chociaż nie wszyscy, ale to my wiemy, że ta osoba jest $z$ innej opcji i staramy się nie rozmawiać na ten temat [...] (Zofia, 69)

Jolantę najbardziej w sytuacji gościny drażni, gdy mężczyźni po alkoholu zaczynają kłótnie na tematy polityczne:

Co mnie drażni? Drażniłoby mnie to, jak kłóca się między sobą. Bo są takie sytuacje nieraz, jak tam brat $z$ bratem sobie coś wypominaja, czy tam tego albo o polityce sie tam sprzeczaja, kłócą. To mnie to denerwuje. No i jak się tak ktoś tam na fest napije, nie. (Jolanta, 42)

Dbanie o spójność grupy to także utrzymywanie relacji równości. „Wywyższanie się”, udawanie kogoś innego, niż się jest („co to nie on”, „nie wiadomo jaka pani”, „manieruje”) piętnowane jest zwłaszcza w wypowiedziach osób z klasy ludowej:

Dobry gość co robi, tak? No, dobry gość zachowuje się normalnie, po ludzku, jak to mówią. No i nie wywyższa się, bo to też bywa, nie? Niektórzy to tam o, manieruja, bo tam coś tam. No bo jest, tak jest. Że chce pokazać co to nie tego, a tu faktycznie jest coś innego. (Zbigniew, 68)

Ale ja miałam sukienkę za 50 zt, gdzie ona miała sukienkę za 300 na przykład, nie? I ona coś tam przypajacuje i tego, nie. Ja mówię, czasami coś skromniejszego lepiej wyglada. [...] Jest taka na pokaz, nie, ale ona taka jest i ja ja taka odbieram, nie, ona ma się za nie wiadomo jaka pania, królowa, tego, nie? (Marzena, 42)

Ale się, się styszy, nie. Jak to jest, nie. Polak pokaże, co to nie on. A później zęby $w$ ścianę, nie. Bo sa tacy. (Jolanta, 64)

Osoby o kapitałach na wysokim poziomie także krytykują postawę tego typu - kłóci się ona $z$ ważną wartością, jaką jest dla nich naturalność, szczerość ( $w$ przeciwieństwie do sztuczności/fałszu/bycia pretensjonalnym). U osób z wysokim poziomem kapitału kulturowego szybko wyłapywane są wysiłki aspirowania do pozycji wyższej niż wynikałoby z posiadanych zasobów. Elity kulturalne nie muszą aspirować, ponieważ ich pozycja jest ugruntowana.

Nie lubię jak ktoś się popisuje. Mamy księdza proboszcza, wykładowcę w seminarium $w$ [nazwa wsi w województwie łódzkim] i jak przyszedt pierwszy raz na kolędę, pyta się, kim jestem z zawodu, zacząt wymieniać jakieś nazwiska [nazwa zawodu], tak jakby każdy musiał znać wszystkich, albo coś tam w obcym języku powiedział. No, nie lubię takich popisów, takiej sztuczności. Niech tam ludzie gadaja o czymkolwiek, ale niech to będzie szczere. (Zofia, 69)

Myślę, że najważniejsze to być naturalnym. To jest chyba najważniejsze: żeby nie ukrywać, że, no nie wiem... cała szkołę stów się zna, to nie o to chodzi, żeby mówić „a $i$ ę. To nie o to chodzi. (Adam, ok. 40) 
Poświęcenie, by zyskać uznanie grupy. Potrzeby innych. Roztaczanie opieki / Niezgoda na poświęcenie. Wtasne potrzeby. Brak opieki - pozostawianie wolności

Jednym $z$ wymiarów familiarności przypisywanej klasie ludowej jest skupienie się bardziej na potrzebach osób bliskich niż na swoich własnych, co jest traktowane jako samonarzucająca się zasada moralna („tak trzeba”) i co może wiązać się z poświęceniem (czasu, pieniędzy, wysiłku, własnych potrzeb). Porównanie wypowiedzi osób z niskimi i wysokimi poziomami kapitałów wskazuje na znaczącą różnicę w tym aspekcie. W wypowiedziach osób o niskich poziomach kapitałów przewija się wątek goszczenia jako pracy. Używane są takie słowa jak: „nagotować”, „narobić”, „usługiwać". Nie dotyczą one codziennego wpadania (jak już wspomniałam, nie jest ono definiowane jako wizyta) ani nowej formuły goszczenia, jaką jest grill w ogrodzie (na ogół składkowy), ale zorganizowanych uroczystości. Zarówno 24-letnia Klaudia, 42-letnia Marzena, jak i 64-letnia Jolanta uważają, że obowiązkiem gospodyni jest wówczas nagotować, a obowiązkiem gościa - zjeść.

Przyjda, zjedza, jak coś przygotuje, że zostawia puste miski. Nawet jak będzie brudno, nieważne, że sprzątałam cały dzień $i$ znowu trzeba będzie posprzątać. Ważne, że jesteśmy uśmiechnięci, zadowoleni, że się spotkaliśmy, porozmawialiśmy. (Klaudia, 24)

Bo tego wymaga kultura, tego wymaga... po to się cztowiek narobit, żeby goście zjedli. Nie po to tyle się nagotowałam, żebym ja to miała potem sama jeść przez trzy dni, tak. Dlatego ja uważam, że jak ktoś to nagotowat, to to trzeba jeść. Mój [imię partnera] to troszeczkę jest innego zdania... on pójdzie skubnie, tego, już ja jego trace, weź i jedz. Gotowała trzy dni - nie widzisz!? Teraz trzy dni będzie to jadła? (Marzena, 42)

Jolanta głęboko wchodzi w rolę gospodyni, której obowiązkiem jest zaspokojenie potrzeb innych. Gdy odwiedziła ją ciotka z mężem, przez cały okres pobytu gotowała dla gości i sprzątała po nich („wszędzie szmaty leżały"). Choć pobyt krewnych był dla niej uciążliwy, nie próbowała w żaden sposób zmieniać reguł gry. Narzekała na zmęczenie, a nawet sugerowała, że ciotka powinna bardziej włączać się w czynności gospodarskie w jej domu (mówiąc, że gdy to ona odwiedza innych, na przykład obiera ziemniaki), ale jednocześnie nie pozwalała odebrać sobie roli poświęcającej się gościom gospodyni-służącej.

Ja ustugiwałam. Ja gotowatam. No tam przyszła do kuchni: może ci coś pomóc? Ja mówię: Nie, nie, idź już sobie siadaj, nie. No ja nie lubię jak mi się tam ktoś placze. [...] No to poszli se tam do miasta, gdzieś tam coś kupiła sobie, coś pochodzili, to tego, czy z mężem pojechali. A ja byłam $w$ domu, pichciłam, nie, no. (Jolanta, 64) 
Jolanta jest przekonana o moralnym obowiązku poświęcenia na rzecz gościa. Uważa za niedopuszczalną sytuację, w której gościna ma charakter symetryczny - a więc goście i gospodarze mają równe prawa i obowiązki. Jako przykład antygościny podaje swoje wyobrażenie holenderskiego modelu odwiedzin, w którym to gość musi ustalić z gospodarzem czy odwiedziny mu pasują oraz partycypować $\mathrm{w}$ poczęstunku:

Będzie tak jak w Holandii. Jak będziesz chciała iść do kogoś, to musisz isś́ ze swoja kawa. I jeszcze zapukać, czy możesz przyjść. (Jolanta, 64).

W wypowiedziach osób z klasy ludowej widoczna jest zdecydowana asymetria pozycji gościa i gospodarza. W sytuacji gościny kluczowe są potrzeby gościa - to przede wszystkim on ma czerpać przyjemność z wizyty. Ten aspekt goszczenia okazał się mocno różnicujący porównywane przeze mnie środowiska. Adam, osoba o bardzo dużym kapitale kulturowym, ma zupełnie inne oczekiwania wobec gościny. Dąży do modelu symetrycznego — nie oczekuje od gospodarza pracy ani poświęcenia, lecz raczej równych reguł - obie strony mają czerpać przyjemność ze spotkania. W modelu symetrycznym każda ze stron dba zarówno o potrzeby innych, jak i swoje. Kiedy Adam jest zmęczony, mówi swoim gościom, że musi się położyć. Kiedy jest gościem, nie oczekuje niczego — noclegu ani jedzenia.

Ja nie wymagam niczego od gospodarza. To nie jest tak, że oczekuje, żeby on mnie nakarmit, napit i jeszcze przenocowat, nie [...] nauczytem się tego, asertywności czy po prostu powiedzenia: sorry, stary, ale musisz iść do domu, bo ja już jestem zmęczony, odpuśćmy sobie na dzisiaj i... no bo muszę się położyć, nie. (Adam, ok. 40)

Adam zdaje sobie sprawę, że poświęcenie jest głęboko wpisane w polską kulturę goszczenia - on uznaje je jednak za obciążające. Uważa, że niekiedy lepiej przenocować w hotelu, by nie robić kłopotu gospodarzom. On również zaakceptowałby sytuację, w której jego gość wybiera hotel:

Wiadomo, że oni by chcieli najlepiej zazwyczaj: a nie, zostań tutaj, gdzieś ci pościelimy, w czwórkę położymy się na jednym łóżku, jeszcze z psem, rybkami i papuga, a ty żebyś miat ten. Ja mówię: no nie, bez przesady, stuchajcie, to jest trzy godziny snu, ja pojadę do hotelu, wiem, gdzie jest hotel, zarezerwowatem, spokojnie, to nie jest żaden problem, nie? I jak im się tak powie, to myślę, że im też jest na rękę, nie? Ale to też jest tak u mnie. Ja w tej chwili robie jakiś tam remont $i . .$. oczywiście mam miejsce do noclegowania, do spania, ale jeśli ktoś mi powie, że woli wynajać hotel, że dojdzie, to OK, ja to rozumiem. Bo ja wiem, że ta osoba może czuć jakiś dyskomfort, tak? (Adam, ok. 40)

Strategia Adama jest przeciwna do strategii Jolanty, która zarówno oczekuje wysiłku od gospodarza, jak i sama się go podejmuje. Adam od- 
wrotnie - ani jako gospodarz, ani jako gość nie chce, by wizyta wiązała się z „absorbowaniem” którejś ze stron:

Szanuje oczywiście każdego, kto przyjdzie do mnie do domu, ale nie chciałbym, aby za bardzo mnie absorbowat. Nie wiem, jak to powiedzieć: wyzbywam się tego, że ja muszę mu dogadzać. Na takiej zasadzie: „a może herbaty”, , , a może kawy?”, , , może ciasta?" Nie, nie, nie, oczywiście, że nie. Chyba nigdy taki nie bytem, ale tego bardzo nie lubię. Oczywiście staram się: stuchajcie, kawa, herbata? Ok. Wiecie, tam na dole jest czajnik. (Adam, ok. 40)

Joanna, Jadwiga i Zofia również preferują bardziej symetryczne modele odwiedzania się. Podczas gdy Jolantę oburza możliwość przychodzenia w gości z własną kawą, u Joanny, Adama i Agnieszki większość spotkań ma charakter składkowy.

To też wyglada bardzo różnie. Na przykład kolega, który mieszka $w$ [nazwa wsi] jest przecudownym kucharzem. [...] Więc to on coś robi. Albo każdy coś przynosi. [...] Zazwyczaj jest tak, że każdy sobie sam przywozi piwo. Alkohol sami. A co sie wydarzy, kto coś weźmie, kto nie weźmie, nie ma jakiegoś większego znaczenia. (Joanna, 34)

Jadwiga, podobnie jak Adam, nie chce być zanadto absorbowana przez gości. Bycie gościnnym to dla niej bycie naturalnym i szczerym, przestrzeganie takich samych wzorów zachowania, jakie obowiązują domowników. Prawdziwie gościnnym jest się wówczas, gdy włączy się gościa do domowej wspólnoty:

Bo jak do mnie przychodza bliskie osoby to wiadomo, że sprzątam trochę i staram się jakoś tam ich ugościć, ale nie, że latam koło każdego, bez przesady. Wychodzę z zatożenia, że jak ja przyjdę do bliskiej mi osoby, to potożę się na kanapę, otworzę lodówkę, powiem, no przynieś mi tam coś. Dla mnie to jest gościnność i bliskość między ludźmi, że nie ma takich barier czy oczekiwań. [...] Talerzy nie chce mi się wymieniać na czyste $i$ koleżanka lubi zarzadzić, że coś komuś. Ja tak nie. Wiadomo, że jak się coś wyleje, ale generalnie wszyscy tak czuja sie jak u siebie $w$ domu. Dzieci się krzataja to też się ich poprosi, żeby coś przyniosty. (Jadwiga, 52)

Zofia swoją potrzebę symetrii wyraża mówiąc, że nie lubi, gdy ktoś chce gościć za bardzo. Zaznacza, że ciągłe zachęcanie do jedzenia jest dla niej krępujące, odwołując się do kategorii dorosłości — „dorośli ludzie wi$\mathrm{dza}$, że jest [na stole]". Koresponduje to $\mathrm{z}$ rozwijaną przeze mnie w innym miejscu (Skowrońska 2019) tezą dotyczącą tego, że — posługując się językiem psychologii transakcyjnej — relacja symetryczna jest na ogół relacją dwojga Dorosłych (w rzadszych przypadkach — dwojga Dzieci lub dwojga Rodziców), podczas gdy relacja asymetryczna na ogół dotyczy relacji Rodzica Opiekuńczego lub Normatywnego z Dzieckiem Podporządkowanym 
lub Spontanicznym. Zofii nie podoba się model, w którym gospodarz-rodzic zanadto opiekuje się gościem-dzieckiem:

Ja się dobrze czuje jako gość, właściwie to widać jakby przy wejściu. Ja nie lubię, jak ktoś mnie chce tak bardzo gościć, jest taki nadmiernie zapraszający. Jest przyjęcie, jest coś na stole, uważam, że dorośli ludzie widza, że jest, że gospodarz zrobit po to, żeby zjedli, i nie musi mnie bez przerwy zachęcać do jedzenia. To jest dla mnie krępujące. (Zofia, 69)

W innym miejscu dystansuje się także od relacji z gospodarzem - Rodzicem Normatywnym. Zofia nie chce, by gospodarz zbytnio kontrolował sytuację, nadawał jej ramy. Podobnie jak Adam, wolałaby współkształtować i negocjować reguły spotkania, zamiast im się poddawać (lub wyznaczać je samodzielnie).

B: Czy jest jakaś wizyta, która pani źle wspomina? Co sprawia dyskomfort jak się jest gościem?

R: Jeżeli gospodarz ma bardzo szczegótowo opracowana $w$ swej głowie rolę tego gościa. Że na przykład tu się zdejmuje buty, takie się kapcie zakłada, tu nie kładź torebki itp. Takie nadmierne skupienie. W obie strony przesada, taki brak swobody. Jeśli gospodarz jest taki nadmiernie ugrzeczniony, to ja się teżźle czuje, a może ja nie potrafie być aż taka szarmancka... (Zofia, 69)

„Po prostu być” versus działać celowo

Ostatnim wymiarem familiarności jest „bycie” w opozycji do działania. Wzorem przypisywanym klasie ludowej jest niechęć wobec rytuałów konwersacyjnych typowych dla klasy średniej. Spotkania nie mają służyć żadnym celom, nie trzeba planować ich przebiegu ani odhaczać punktów programu. Nie trzeba ich niczym urozmaicać, szukać dodatkowej formuły (takiej jak wieczór filmowy, wieczór gier, wspólne gotowanie). Kluczowe jest współbycie, odtwarzanie i afirmowanie codzienności.

B: A jak Pani rozumie gościnnosśc? Co to znaczy dla Pani?

R: Samo to, że miło się spędzi czas. Nie musi być nic. Ważne, że się spotkamy i porozmawiamy. (Klaudia, 24)

Takie nastawienie wybrzmiewa $\mathrm{w}$ opowieściach Zbigniewa i Jolanty. W narracji Jolanty widać, że rozmowa pełni funkcję fatyczną, nie musi prowadzić do żadnego celu ani nic rozstrzygać.

A tak znajomych z bloku to ma się dużo. O się pogada, czy na dziatkę jak się idzie, to idzie się razem. Czy się na dziatce spotkamy. One maja tu, a my tu i się tam, o, zagada. To a tamto. [...] Tak, tak, no tak o dzieciach, o, o, co w sklepie. A tam kto umart, nie. Albo kto tam, o takie tam. Takie pierdoty, nie [śmiech drugiej osoby], dostownie. [...] Takie ogólne, ogólne. Jak się tam żyje. Jak zdrowie, o tak, o. (Jolanta, 64) 
Jedynie w narracjach młodszego pokolenia, Klaudii i przede wszystkim Marzeny, obecne są inne wątki - co współgra $z$ tezą o tym, że nowe pokolenia klasy ludowej częściowo dystansują się od rodzinnych wzorów, są podatne na mechanizmy mody (Gdula, Lewicki, Sadura 2014; por. Zalewska, Cobel-Tokarska 2014). Marzena, jak już kilkakrotnie wspomniałam, poszukuje nowości i zmian. Wyraża się to między innymi w organizowaniu tematycznych spotkań, na których „coś się robi” - a nie tylko jest. Są to przebierane imprezy, wycieczki, wyjścia na kręgle. Również u Klaudii pojawia się nowy wzór spędzania czasu z gośćmi — gry. Podkreśla ona jednak, że gra to tylko dodatek do spotkania, którego esencją jest rozmowa, bycie razem:

To, że się tak przeciagnęto, że się podobało. To, że wszyscy byli zadowoleni z tej imprezy. Udało się, posiedzieliśmy, pogadaliśmy, pograliśmy. [...] W planszówki, xboxy też. Byto sporo osób, więc często się zmienialiśmy. Graliśmy na początku, żeby rozluźnić atmosferę. [...] Później chowamy, żeby trochę porozmawiać. I można później też wyciagnać znowu. Gra jest dodatkiem do spotkania. (Klaudia, 24)

Opowieści osób dysponujących kapitałami na wysokim poziomie wskazują na silne wzorce działania lub rozmów na tematy wykraczające poza codzienność. Zarówno Jadwiga, jak i Zofia wspominają spotkania wokół tematów literackich i historycznych. U Jadwigi gra się również w szachy i gry planszowe.

Tam w holu mam szachy. Czasami ktoś musi zagrać z moim młodszym synem. I wtedy to chodź zagramy szybka partyjkę $i$ to się przeradza... Mojej córki chrzestny lubi gry, puzzle i układamy też, ludzie sie gromadza wokót. Mamy dużo miejsca tutaj. Maż jednej koleżanki jest historykiem z zamiłowania. Ona go ucisza, ale niektórzy mówia "no to chodź opowiedz" $i$ on to bardzo lubi. Teraz wyszła ksiażka [...] poświęcona grupie Greków, którzy tutaj po tej wojnie przyjechali. Ona byta w różnych mediach. Jedna taka z imprez, to chyba potowa osób byta na tym skupiona. My mamy ta ksiażkę, maż przeczytat $i$ byto cytowanie, rozmowa o historii. (Jadwiga, 52)

[...] zaczęła się dyskusja na temat święta [15 sierpnia]. Wtaczyt pieśni patriotyczne polskie i siostrzenica była zachwycona. Siedziatyśmy chyba ze trzy godziny. To sa takiego rodzaju kontakty, że można sobie iść $i$ w sumie się ciesza wszyscy. (Zofia, 69)

Także w młodszym pokoleniu, u Agnieszki, Joanny i Adama, nie brakuje spotkań, na których „coś się robi” — gra, gotuje, a nawet koncertuje.

$W$ dwa miesiace złożyliśmy muzykę do tych tekstów i zrobiliśmy jej koncert niespodziankę. Ze świecami taki wiesz klimatyczny. Trzech chtopaków. Wszyscy w dredach byli na czarno ubrani, ja na biało i po prostu zaśpiewaliśmy jej koncert niespodziankę. I tego typu mamy urodziny. Tak się gościmy urodzinowo. (Joanna, 34)

Na przykład ostatnio tak byto, że no to teraz robimy każdy wybiera jakaśs piosenkę, którą chciatby postuchać nagle. Nie teraz stucha i się tak fajnie to rozkręcito, każdy 
miat swoją turę, która tam leciała. I to się przedłużyto o dwie, trzy godziny. Bardzo różnie jest. Gramy w gry planszowe na przykład. W gry, w karty na przykład też. (Joanna, 34).

Choć tego rodzaju spotkania są dla rozmówców czymś naturalnie wpisanym w ich życie towarzyskie, nie wyklucza to zaniku w tej grupie kategorii „po prostu być”. Co ważne, kategoria „działanie” nie może łączyć się z nadmiernym planowaniem, kontrolowaniem ani sztywnością ról. Wówczas kłóciłaby się z kluczową dla tej frakcji klasy średniej kategorią naturalności.

\section{Substancjalność/forma}

Mięsność, sytosśc, obfitość versus lekkość, powstrzymywanie sie

Trzecim rodzajem analizowanych dyspozycji są te skupione wokół rozróżnienia na formę i substancję - w teorii Bourdieu nastawienie na substancję jest jedną z kluczowych dyspozycji klasy ludowej, w przeciwieństwie do klas średnich, dla których liczy się forma. Bourdieu szukał przykładów formy i substancji między innymi w jedzeniu. Podczas gdy klasa ludowa w jego badaniach jest skupiona na substancji - je obficie, preferując potrawy tłuste i pożywne, którymi można się nasycić, klasa średnia zwraca uwagę na estetykę dań, woli dania lżejsze i unika przejadania się. Podobne tendencje (zgodnie $z$ tezą o homologii dyspozycji) Bourdieu śledzi na przykład w urządzaniu wnętrz (praktyczność kontra estetyka i dekoracyjność). W omawianych przeze mnie badaniach dyspozycje wokół opozycji forma-substancja okazały się dość trudne do prześledzenia przede wszystkim dlatego, że nie były uwzględniane w pytaniach badawczych (a więc nie były przełożone na pytania wywiadu).

Trudno jednoznacznie stwierdzić, w jakim stopniu opozycja forma-substancja $\mathrm{w}$ jedzeniu jest różnicująca $\mathrm{w}$ przypadku badanych grup. Z pewnością w wypowiedziach Zbigniewa, Jolanty, Karoliny i Sandry (osób o niskich poziomach kapitałów) pojawiają się wątki obfitości i mięsności potraw - przygotowywanie imprez $\mathrm{w}$ zasadzie zawsze wiąże się z pieczeniem lub smażeniem mięsa.

[...] te pieczone mięsa wchodza teraz też na grilla, na przykład wołowina, czy tam boczek podpiekany. (Zbigniew, 68)

No jakieś tam kurczak, dewolaje moga być. (Jolanta, 64)

Mięsko upiekłam, sałatkę zrobitam. (Sandra, 24)

Ona zrobiła sałatkę, ja zrobiłam mięso. (Karolina, 38) 
Smalczyk $z$ mięskiem, sam smalczyk, masetko, wszystko mieli tak na podgrzewaczach, żeby nie byto, bo to tego... To byto ta pajda chleba, gwoździem programu, znaczy gwoździem programu była kietbasa, wiadomo, bo to wszyscy mówili, że kietbasa na kiju. (Marzena, 42)

Na pewno na proszonych spotkaniach jada się dużo („żona nie wychodzi z kuchni”, „gotowała trzy dni”, „Tylko żona ma taki zwyczaj, że ona naszykuje. I tych sałatek! Tego wszystkiego! No mnóstwo tego jedzenia"). Jednocześnie widać jednak wpływ mody na zdrowe odżywianie, sygnalizowany przez Marzenę (sałatka ze szpinaku) i Zbigniewa (zwiększająca się liczba sałatek), a wypowiedzi osób z drugiej grupy wskazywały, że większe spotkania także wiążą się ze spożywaniem sporych ilości jedzenia. Jednak po pierwsze: żadna $z$ tych osób nie wspomniała o mięsie, podczas gdy w pierwszej grupie - wszyscy. Po drugie, w grupie osób o wysokich kapitałach o jedzeniu mówiono raczej w kontekście pasji, przyjemności gotowania i eksperymentowania niż sytości i obfitości.

Treść zamiast formy: nieprzywiazywanie wagi do estetyzacji, dekoracji versus estetyzacja, dekoracyjność

Wydaje się, że tym, co łączy obie analizowane grupy, jest brak skupienia na dekoracyjności, na przykład na zdobieniu stołu, serwetkach, specjalnych talerzach, odpowiedniej prezentacji potraw. Wśród osób o niskich poziomach kapitałów temat po prostu się nie pojawił. W drugiej grupie pojawił się jako antywzór. Przeciwstawieniem formy była w tym przypadku może nie tyle substancja, ile esencja - to, co prawdziwe i istotne (w gościnie tą esencją jest uważność wobec drugiego człowieka).

Dla mnie kontakt z czlowiekiem jest najważniejszy, absolutnie. I nie ma znaczenia, czy gościnnoś́́ jest u mnie, u niego $w$ domu, czy spotkanie $w$ lesie, $w$ parku, gdziekolwiek. No, to jest dla mnie najważniejsze i chyba ta gościnność tak się właśnie objawia. (Adam, ok. 40)

I wcale nie musza to być takie rzeczy, to nie jest tak, że gościnność to jest pięknie nakryty stół $z$ wystawnymi filiżankami, kwiatami itd. Nie to bardziej chodzi o atmosferę. Bycie razem i takiej radości z bycia ze sobą. (Agnieszka, 34)

\section{ZAKOŃCZENIE}

Zainteresowanie klasowością codziennych praktyk napotyka niebezpieczeństwo wynikające $z$ uproszczeń sposobu doboru próby i interpretacji materiału. Mam tu na myśli zwłaszcza trójpodział na klasy niższe, średnie 
i wyższe czy stosowany w wielu badaniach ilościowych podział ze względu na sytuację zawodową, który łączy w jedną kategorię osoby o czasami bardzo różnych dyspozycjach. Wychodzę z założenia, że metodą pozwalającą na największe zniuansowanie i precyzję wyników jest dobór próby ze względu na (maksymalne) zróżnicowane wysokości trzech rodzajów kapitału. Kolejnym uproszczeniem jest badanie korelacji między klasą a konkretną praktyką, taką jak czytanie książek czy jedzenie krewetek. O wiele bogatsze i mniej schematyczne wnioski można wyciągnąć, przyglądając się dyspozycjom (ogólnym tendencjom, motywom, pewnej filozofii działania), które przejawiają się w wielu różnych praktykach na zasadzie homologii (Bourdieu 2005). Przedmiotem uwagi uczyniłam tutaj dyspozycje dwóch klas społecznych. $Z$ jednej strony interesowała mnie frakcja klasy ludowej o niskich poziomach kapitału wszystkich typów, z drugiej frakcja klasy średniej o relatywnie wysokich poziomach wszystkich kapitałów (zwłaszcza kulturowego; sytuacja finansowa respondentów z wysokim kapitałem kulturowym była relatywnie korzystna w skali lokalnej, ale nie w skali kraju).

Ponieważ te rozważania opierały się na wynikach badań jakościowych, a dodatkowo dobór próby nie został przeprowadzony w pełni w sposób początkowo zaplanowany, zasięg wniosków jest ograniczony. Interesujące wydaje się jednak to, że w ich świetle występujące w literaturze dychotomie, które przypisują klasie ludowej, w opozycji do klasy średniej, familiarność, substancjalność i konwencjonalność, okazują się zbyt upraszczające $z$ dwóch powodów. Po pierwsze dlatego, że każda $z$ tych dyspozycji to raczej zbiór, który należy analizować bardziej szczegółowo, przyglądając się osobno jego różnym wymiarom. Na przykład podczas gdy takie aspekty familiarności jak luz, swoboda i żart łączyły obie badane przeze mnie klasy, inne - jak skłonność do poświęceń - znacząco je różnicowały. Po drugie, zbyt upraszczające i substancjalne byłoby uznanie, że analizowane przeze mnie dyspozycje dzieliły bądź łączyły przedstawicieli klasy ludowej i średniej. Trafniej byłoby raczej stwierdzić, że niektóre z dyspozycji są bardziej prawdopodobne jako cechy osoby o wysokich poziomach kapitału ekonomicznego i społecznego oraz bardzo wysokim poziomie kapitału kulturowego niż osoby o niskich poziomach tych kapitałów (lub przeciwnie). Jeśli potraktowalibyśmy klasę ludową i średnią zbyt szeroko, nie uwzględniając zróżnicowań w obrębie poszczególnych typów kapitału, wyniki mogłyby okazać się zupełnie inne.

Kolejna istotna kwestia to uwzględnienie wieku/pokolenia, który okazał się istotnym czynnikiem zróżnicowania praktyk. W przyszłych badaniach kluczowe będzie uwzględnienie pozycji społecznej rodziców i tego, 
czy obecna pozycja społeczna badanego jest wynikiem awansu. To mogłoby tłumaczyć różnice praktyk gościny podejmowanych w stosunku do rodziców i przyjaciół, które zostały ujawnione w środowisku osób dysponujących kapitałami na wysokim poziomie.

Na koniec chciałabym wskazać na to, że kilka wzorów praktyk nie różnicowało badanych grup — okazywały się równie intensywne w przypadku osób zarówno z wysokimi, jak i niskimi poziomami kapitałów. Były to: luz i swoboda, dążenie do porozumienia i solidarność grupowa, a także niechęć do estetyzacji i dekoracyjności. Co ciekawe, różnicujące były czasami niuanse - ogólna zasada praktyki mogła być taka sama, ale różnicujące okazywały się uzasadnienia czy motywacje, które stały u jej podstaw. Dla osób o wysokim poziomie kapitałów takim ważnym uzasadnieniem była naturalność/szczerość - w przeciwieństwie do fałszu, sztuczności i pretensjonalności. Wydaje się, że to uzasadnienie jest pewną metazasadą przenikającą wiele pozostałych wzorów.

\section{BIBLIOGRAFIA}

Albala Ken, 2013, Routledge International Handbook of Food Studies, Routledge, London-New York.

Borkowska Iwona, Jakubowska Honorata, Podgórski Michał, 2009, Metodologia dla socjologii codzienności. Próba dojrzenia niewidzialnego i uniknięcia pułapek widzialnego, w: Seweryn Rudnicki, Justyna Stypińska, Katarzyna Wojnicka (red.), Społeczeństwo i codzienność. W strone nowej socjologii?, Wydawnictwa Akademickie i Profesjonalne, Warszawa.

Bourdieu Pierre, 2005, Dystynkcja. Społeczna krytyka władzy sądzenia, tłum. Piotr Biłos, Scholar, Warszawa.

Cebula Michał, 2017, Analiza klasowa na rozdrożu? W stronę kulturowej koncepcji klas P. Bourdieu, „Studia Socjologiczne”, nr 3, s. 33-69.

Cieśla Joanna, 2017, Sondaż POLITYKI: Jak Polacy postrzegają samych siebie?, „Polityka”, 12 maja.

Derrida Jacques, 2000, Of Hospitality, Stanford University Press, Stanford.

Derrida Jacques, 2004, Gościnność nieskończona, „Przegląd Filozoficzno-Literacki”, nr 3.

Devine Fiona, 2004, Class Practices, Cambridge University Press, Cambridge.

Douglas Mary, Isherwood Baron, 1979, The World of Goods: Towards an Anthropology of Consumption, Routledge, London.

Drozdowski Rafał, Fatyga Barbara, Filiciak Mirosław, Krajewski Marek, Szlendak Tomasz (red.), 2014, Praktyki kulturalne Polaków, Wydawnictwo Naukowe UMK, Toruń.

Gdula, Maciej, Lewicki Mikołaj, Sadura Przemysław, 2014, Praktyki kulturowe klasy ludowej, Instytut Studiów Zaawansowanych, Warszawa.

Goffman Erving, 2006, Rytuat interakcyjny, tłum. Alina Szulżycka, Wydawnictwo Naukowe PWN, Warszawa.

Goffman Erving, 2008, Człowiek w teatrze życia codziennego, tłum. Helena Datner-Śpiewak, Paweł Śpiewak, Aletheia, Warszawa.

Hanson Julienne, 1999, Decoding Homes and Houses, Cambridge University Press, Cambridge. 
Hermann Marcin, 2010, Powody do dumy i wstydu dla Polaków. Komunikat z badań, CBOS, Warszawa.

Hoggart Richard, 1976, Spojrzenie na kulturę robotnicza w Anglii, tłum. Aleksandra Ambros, Państwowy Instytut Wydawniczy, Warszawa.

Homans George C., 1958, Social Behavior as Exchange, „American Journal of Sociology”, t. 63(6), s. 597-606.

Jacyno Małgorzata, 2007, Kultura indywidualizmu, Wdawnictwo Naukowe PWN, Warszawa.

Knorr-Cetina Karin, 2001, Objectual Practice, w: Theodore Schatzky, Karin Knorr-Cetina (red.), The Practice Turn in Contemporary Theory, Routledge, London.

Leder Andrzej, 2014, Prześniona rewolucja, Wydawnictwo Krytyki Politycznej, Warszawa.

Łuczaj Kamil, 2018, Ku biograficznemu badaniu doświadczenia klasy ludowej. Krytyka metodologicznego podejścia Pierre'a Bourdieu, „Studia Socjologiczne”, nr 2, s. 93-114.

Marody Mirosława, Giza-Poleszczuk Anna, 2004, Przemiany więzi społecznych, Scholar, Warszawa.

Mateja Bogumiła, Skowrońska Marta, 2019, Gość w dom. Wspótczesne praktyki gościny, Wydawnictwo Naukowe UAM, Poznań.

Mauss Marcel, 2011, Szkic o darze, w: Marcel Mauss, Socjologia i antropologia, tłum. Marcin Król, Krzysztof Pomian, Jerzy Szacki, Wydawnictwo KR, Warszawa.

Omyła-Rudzka Małgorzata, 2015, Autoportret Polaków i postrzegany dystans kulturowy wobec sasiadów. Komunikat $z$ badań, CBOS, Warszawa.

Pakulski Jan, Waters Malcolm, 1996, The Death of Class, Sage Publications, London.

Pakulski Jan, 2005, Śmierć klas, w: Encyklopedia socjologii. Suplement, Oficyna Naukowa, Warszawa.

Pisarek Adam, 2016, Gościnność polska: o kulturowych konkretyzacjach idei, Wydawnictwo Uniwersytetu Śląskiego, Katowice.

Rancew-Sikora Dorota, Żadkowska Magdalena, 2017, Receiving Guests at Home by Nationally Mixed Couples: The Case of Polish Females and Norwegian Males, „Studia Migracyjne - Przegląd Polonijny", nr 4.

Reckwitz Andreas, 2002, Toward a Theory of Social Practices: A Development in Culturalist Theorizing, „European Journal of Social Theory”, t. 5(2), s. 243-263.

Rosello Mireille, 2001, Postcolonial Hospitality: The Immigrant as Guest, Stanford University Press, Stanford.

Savage Mike, 2016, The Fall and Rise of Class Analysis in British Sociology, 1950-2016, „Tempo Social", t. 28(2), s. 57-72.

Savage Mike i in., 2013, A New Model of Social Class? Findings from the BBC's Great British Class Survey Experiment, „Sociology”, t. 47(2), s. 219-250.

Schatzki Theodore R., 2002, Site of the Social: A Philosophical Account of the Constitution of Social Life and Change, Penn State University Press, University Park.

Simmel Georg, 2005, Socjologia, tłum. Małgorzata Łukasiewicz, Wydawnictwo Naukowe PWN, Warszawa.

Tönnies Ferdynard, 1988 [1887], Wspólnota i stowarzyszenie. Rozprawa o komunizmie i socjalizmie jako empirycznych formach kultury, tłum. Małgorzata Łukasiewicz, Państwowe Wydawnictwo Naukowe, Warszawa.

Zalewska Joanna, Cobel-Tokarska Marta, 2014, Od obyczaju do mody: Przemiany życia codziennego, Akademia Pedagogiki Specjalnej, Warszawa. 
Zarycki Tomasz, 2012, W poszukiwaniu użytecznej przeszłości: skąd wywodzi się polska klasa średnia, „Res Publica Nowa”, nr 18.

\title{
THE CLASS DIMENSION OF HOSPITALITY: THE DIVERSITY OF DISPOSITIONS ORGANIZING HOSPITALITY PRACTICES \\ Marta Skowrońska \\ (Adam Mickiewicz University in Poznań)
}

\begin{abstract}
This article looks at hospitality practices in the process of recreating and modifying social structure. The author seeks the general regularities and behavioral patterns that appear when people visit others and are visited, as well as how they speak of these visits, or, in Pierre Bourdieu's language, the principles that organize practices that are part of the class habitus. For the purposes of the analysis, two comparative groups were selected: people with the highest and lowest levels of economic, social, and cultural capital. The analysis allowed several conclusions to be drawn. First, in addition to the class factor, the age or generational factor should be taken into account as it has proven to be relevant in terms of the diversity of practices. Second, the research showed that several of the practices studied were not differentiated between the groups; they turned out to be intense in the case of people with high and low levels of capital. Such patterns involved informality and freedom, the striving for agreement and group solidarity, and an aversion to aesthetics and decoration. Third, there were sometimes differentiating nuances-the general principle could be the same, but the justification or motivation behind it was different. For people with a high level of both types of capital, naturalness/honesty was an important justification and was contrasted to falsehood, artificiality, and pretentiousness. This justification seemed to be a meta-principle that permeated many other patterns of behavior.
\end{abstract}

Key words: hospitality, social practices, habitus, social class

Stowa kluczowe: gościnność, praktyki społeczne, habitus, klasy społeczne 